\title{
DAYA SAING EKSPOR PRODUK MAKANAN OLAHAN INDONESIA KE TIMUR TENGAH
}

\section{The Competitiveness of Indonesian Processed Food Export to the Middle East}

\author{
Hasni \\ Pusat Pengkajian Perdagangan Luar Negeri, BPPP, Kementerian Perdagangan-RI, \\ JI. M.I. Ridwan Rais No.5 Jakarta Pusat 10110, Indonesia \\ e-mail: hasni.melati@gmail.com
}

Naskah diterima: 13/02/2018; Naskah direvisi: 04/04/2018; Disetujui diterbitkan: 12/11/2018

Dipublikasikan online: 31/12/2018

\begin{abstract}
Abstrak
Penelitian ini bertujuan untuk menganalisis daya saing ekspor produk makanan olahan Indonesia di sepuluh negara Timur Tengah dan rekomendasi kebijakannya. Data yang digunakan adalah data sekunder dan diolah dengan metode RCA dinamis. Hasil penghitungan RCA dinamis menunjukkan bahwa posisi daya saing produk makanan olahan dengan kategori Lagging Opportunity dan Lost Opportunity berpotensi untuk ditingkatkan ekspornya ke Timur Tengah. Produk makanan olahan yang perlu ditingkatkan ekspornya adalah minuman ringan, snack/camilan dan makanan olahan lainnya. Peningkatan ekspor produk makanan olahan ke Timur Tengah dapat dilakukan dengan cara a) meningkatkan peran Atase Perdagangan dan ITPC untuk memperoleh informasi pasar, serta melakukan promosi ekspor, b) melakukan koordinasi di dalam dan luar negeri untuk memperoleh sertifikasi keamanan produk makanan olahan yang berorientasi ekspor, c) mempercepat perjanjian perdagangan untuk memperluas akses pasar melalui penurunan tarif impor makanan olahan dari Indonesia, d) memberikan pelatihan dan pendampingan kepada eksportir UKM termasuk desain dan pengemasan, dan e) merundingkan penyederhanaan dokumen ekspor dengan biaya yang terjangkau.
\end{abstract}

Kata Kunci: Makanan Olahan, Ekspor, Timur Tengah, RCA Dinamis

\begin{abstract}
The objectives of this study are to analyze the competitiveness of Indonesian processed food exports in the ten Middle East countries and formulate recommendations to increase Indonesia's processed food exports to those countries. The data used in this study was secondary data and estimated by using dynamic RCA method. By using the dynamic RCA method, it was found that the position of the competitiveness of processed food products in the Lagging Opportunity and Lost Opportunity categories have potential to be increased as exports products to the Middle East. These processed products are soft drinks, snacks and other processed foods. The processed food products export to the Middle East can be increased by: a) encouraging Indonesia's Trade Representatives (Trade Attaches and ITPC) to facilitate doing business between Indonesia and Middle East, b) coordinating domestic and foreign stakeholders to obtain export-oriented food safety certification, c) accelerating the establishment of trade agreements to expand market access through reduced tariffs on imported processed foods from Indonesia, d) increasing competitiveness of export products by providing training and assistance to SME exporters including design and packaging, and e) Negotiating to simplify export documents process at affordable costs.
\end{abstract}

Keywords: Processed Food, Export, Middle East, Dynamic RCA

JEL Classification: C02, F13, H30, O24 


\section{PENDAHULUAN}

Salah satu tujuan penting Kementerian Perdagangan adalah meningkatkan ekspor barang non migas yang bernilai tambah dan jasa (Kementerian Perdagangan, 2015). Sektor makanan olahan merupakan salah satu andalan ekspor Indonesia, hal ini terlihat dari fakta bahwa di tengah melambatnya kinerja ekspor non migas, ekspor makanan olahan masih tumbuh 5,8\% per tahun selama periode 2012-2016, sedangkan ekspor non migas mengalami perlambatan $8,1 \% /$ tahun pada periode yang sama (BPS, 2017a). Oleh karena itu, peningkatan ekspor makanan olahan diharapkan dapat memacu peningkatan ekspor non migas. Industri makanan olahan penting dikembangkan karena kontribusi industri makanan, minuman dan tembakau terhadap PDB pada tahun 2014 mencapai 7,15\%, berada pada posisi kedua dalam sektor industri pengolahan setelah industri alat angkut, mesin dan peralatannya yang menyumbang 8,75\% (BPS, 2017b).

Dalam upaya peningkatan kinerja ekspor nasional, perlu dilakukan diversifikasi ekspor ke pasar non tradisional seperti negara-negara di kawasan Timur Tengah. Negara tradisional adalah negara yang selalu masuk dalam 5 besar sebagai negara tujuan ekspor non migas Indonesia selama 42 tahun terakhir sejak tahun 1970-2011, yaitu Uni Eropa, Jepang dan Amerika Serikat. Sedangkan negara lainnya didefinisikan sebagai negara non tradisional (Puskadaglu, 2013). Hal ini dimaksudkan agar kinerja ekspor nasional agar tidak bergantung pada negara tradisional yang sudah menjadi mitra dagang utama, tapi juga membuka akses pasar baru yang potensial seperti negara di kawasan Timur Tengah. Perekonomian Timur Tengah yang diprediksi tumbuh 3,1\% di tahun 2017 dan 3,3\% di tahun 2018 diyakini dapat menjadi tujuan pasar makanan olahan yang menjanjikan. Namun disisi lain, terdapat beberapa hambatan dalam upaya meningkatkan ekspor makanan olahan ke kawasan tersebut. Salah satu hambatan tersebut adalah mahalnya biaya untuk melengkapi dokumen ekspor ke beberapa negara di Timur Tengah.

Pasar ekspor harus dievaluasi sesuai dengan kriteria yang paling penting yaitu ekonomi, politik, sosial dan teknologi, sehingga target pasar ekspor dapat diidentifikasi dengan lebih baik (Miečinskienè et.al., 2014). Berdasarkan data Trademap (2017), impor kawasan Timur Tengah untuk 
barang konsumsi seperti makanan olahan mencapai USD 14 miliar di tahun 2015. Sementara itu, impor makanan olahan Timur Tengah dari Indonesia tahun 2015 baru sekitar USD 248 juta atau masih sekitar 1,2\% terhadap impor makanan olahan Timur Tengah dari dunia. Namun demikian tren impor makanan olahan asal Indonesia masih menunjukkan peningkatan rata-rata $9,1 \%$ per tahun selama periode 2011-2015. Hal ini tentunya menjadikan Timur Tengah merupakan kawasan yang cukup menarik dan potensial sebagai kawasan target peningkatan tujuan ekspor non migas Indonesia, khususnya makanan olahan.

Belum ada penelitian yang melihat secara komprehensif daya saing produk ekspor makanan olahan Indonesia ke Timur Tengah. Padahal Timur Tengah merupakan kawasan yang memiliki potensi besar untuk peningkatan ekspor produk makanan olahan Indonesia. Jumlah penduduk Timur Tengah yang mencapai 297 juta jiwa dan perekonomian yang tergolong stabil dengan perkiraan rata-rata pertumbuhan PDB sebesar 1,1\% hingga 2019 (World Bank, 2017). Pemasok makanan olahan di Timur Tengah masih didominasi oleh negara- negara dari kawasan Uni Eropa dan Timur Tengah sendiri. Sedangkan pangsa makanan olahan Indonesia di pasar Timur Tengah masih relatif rendah, hanya mencapai $1,2 \%$ di tahun 2015 (Trademap, 2017).

Penelitian ini bertujuan untuk menganalisis daya saing ekspor produk makanan olahan Indonesia di sepuluh negara Timur Tengah, dimana produk makanan olahan berdasarkan HS 6 digit dilihat posisi daya saingnya di negara-negara tersebut dengan menggunakan metode RCA dinamis. Dari hasil analisis diharapkan terlihat bagaimana posisi daya saing ekspor produk makanan olahan Indonesia. Selanjutnya untuk menghasilkan rekomendasi kebijakan untuk dapat meningkatkan ekspor produk makanan olahan Indonesia di Timur Tengah dilakukan analisis prioritas alternatif strategi untuk meningkatkan ekspor makanan olahan Indonesia ke Timur Tengah dengan menggunakan metode Analytic Hierarchy Process (AHP).

\section{METODE}

Metode Revealed Comparative Advantage (RCA) dinamis, pertama kali diperkenalkan pada tahun 2001 oleh Edwards \& Schoer untuk menganalisis daya saing perdagangan Afrika Selatan. Menurut Widyasanti (2010) 
keuntungan menggunakan RCA mengelompokkan produk berdasarkan dinamis adalah: (i) mampu posisi mereka dalam pasar sehingga mendeskripsikan RCA seiring waktu; RCA dinamis lebih bermanfaat dan (ii) dapat menentukan kedudukan produk dalam negara-negara tujuan ekspor, dimana indikator ini dibandingkan RCA tradisional. Indeks RCA dinamis dirumuskan sebagai berikut (Edwards \& Schoer, 2001):

$$
\frac{\Delta R C A_{j}}{R C A_{j}}=\frac{\Delta\left(X_{i, j} / \sum_{j} X_{i, j}\right)}{X_{i, j} / \sum_{j} X_{i, j}}-\frac{\Delta\left(X_{w, j} / \sum_{j} X_{w, j}\right)}{X_{w, j} / \sum_{j} X_{w, j}}
$$

dimana:

$\mathrm{RCA}_{\mathrm{j}}$ : Indeks daya saing makanan olahan Indonesia di negara Timur Tengah

$X_{i j}$ : Ekspor makanan olahan Indonesia ke negara Timur Tengah

$X_{w j} \quad$ : Ekspor makanan olahan dunia ke negara Timur Tengah

I : Indonesia

w : Dunia

j : Produk makanan olahan

Dalam persamaan 1, bagian pertama pada sebelah kanan tanda sama dengan (Right Hand Side) mencerminkan pertumbuhan dalam pangsa komoditas j dalam total perdagangan Indonesia; sementara bagian kedua mencerminkan pertumbuhan dalam pangsa komoditas j dalam perdagangan dunia. Hasil RCA dinamis selanjutnya digambarkan dalam matriks penempatan daya saing ekspor (Tabel 1).

Tabel 1. Matriks Penempatan Daya Saing Ekspor

\begin{tabular}{|c|c|c|c|c|c|}
\hline & $\begin{array}{c}\text { Pangsa } \\
\text { komoditi j pada } \\
\text { ekspor } \\
\text { Indonesia } \\
\end{array}$ & & $\begin{array}{c}\text { Pangsa } \\
\text { komoditi j pada } \\
\text { ekspor Timur } \\
\text { Tengah }\end{array}$ & & isis \\
\hline $\begin{array}{l}\text { RCA } \\
\text { naik }\end{array}$ & $\begin{array}{l}\uparrow \\
\uparrow \\
\downarrow\end{array}$ & $\begin{array}{l}> \\
> \\
>\end{array}$ & $\begin{array}{l}\uparrow \\
\downarrow \\
\downarrow\end{array}$ & $\begin{array}{l}\text { Bintang bersinar } \\
\text { Bintang redup } \\
\text { Sedang mundur }\end{array}$ & $\begin{array}{l}\text { Rising stars } \\
\text { Falling stars } \\
\text { Lagging retreat }\end{array}$ \\
\hline $\begin{array}{l}\mathrm{RCA} \\
\text { turun }\end{array}$ & $\begin{array}{l}\downarrow \\
\downarrow \\
\uparrow\end{array}$ & $\begin{array}{l}< \\
< \\
<\end{array}$ & $\begin{array}{l}\uparrow \\
\downarrow \\
\uparrow \\
\end{array}$ & $\begin{array}{l}\text { Kehilangan peluang } \\
\text { Peluang tertinggal } \\
\text { Kesempatan hilang }\end{array}$ & $\begin{array}{l}\text { Lost opportunity } \\
\text { Leading retreat } \\
\text { Lagging opportunity }\end{array}$ \\
\hline
\end{tabular}

Sumber: Edwards \& Schoer dalam Widyasanti (2010) 


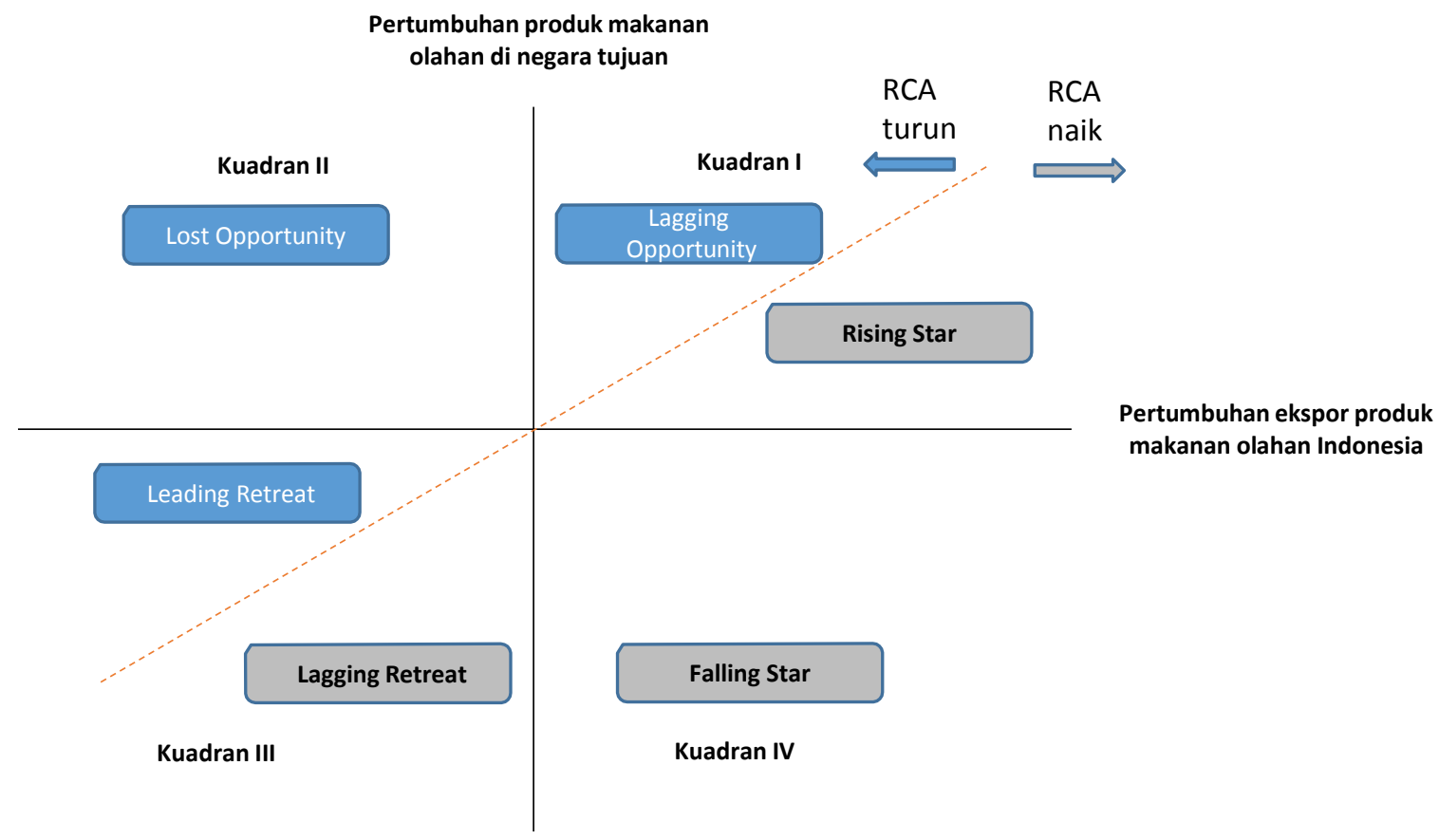

\section{Gambar 1. Posisi Daya Saing Produk Ekspor Menggunakan RCA Dinamis}

Sumber: Widyasanti (2010), diolah

Daya saing suatu negara di pasar dunia menentukan perkembangan dan pertumbuhan kinerja perdagangannya. Daya saing terhadap suatu produk ekspor menjadi kunci bagi peningkatan ekspor suatu negara. Oleh karena itu, setiap negara berupaya meningkatkan keunggulan komparatifnya agar menjadi lebih efisien dibandingkan dengan produk negara lain hingga dapat menjadi produk berdaya saing.

Beberapa penelitian telah dilakukan guna mengetahui daya saing suatu produk di beberapa negara di dunia, Ozcelik \& Erlat (2013) menganalisis daya saing produk negara Turki serta posisi pasarnya di
Uni Eropa. Penentuan daya saing dianalisis melalui RCA dan RCA dinamis. Hasil penelitian menunjukkan bahwa kendaraan bermotor, bahan bangunan tanah liat, jaket perempuan, kain rajutan, sanitasi, pipa dan pemanas, buah, serta aksesori pakaian merupakan produk sektor tiga digit yang memiliki nilai $\mathrm{RCA}$ yang tertinggi (RCA $>1)$. Penelitian ini menyimpulkan bahwa sebagian besar dari produk ekspor Turki mengalami penurunan pangsa ekspor di pasar Uni Eropa.

Sementara itu, Kathuria (2013) melakukan penelitian serupa terkait daya saing ekspor pakaian untuk negara India dan Bangladesh 
menggunakan pendekatan RCA menjanjikan bagi Indonesia. $\mathrm{Di}$ lihat dinamis. Penelitian menunjukkan bahwa pada tahun 1995 India dan Bangladesh memiliki keunggulan komparatif dan berdaya saing pada pakaian dengan jumlah masing-masing 23 produk pakaian dari 34 produk untuk India dan 21 produk pakaian dari 34 produk pakaian untuk Bangladesh. Ditinjau lebih dalam dari hasil analisis RCA dinamis bahwa kedua negara tersebut memiliki daya saing pada produk yang serupa yaitu pada produk dengan kode HS 61 dan 62.

Widyasanti (2010) menganalisis perdagangan bebas regional dan daya saing ekspor dengan studi kasus Indonesia. Pada penelitian ini daya saing yang diteliti merupakan daya saing produk Indonesia yang terlibat dalam perdagangan bebas dalam kerangka Asean Free Trade Area (AFTA) dan Asean China Free Trade Area (ACFTA) pada tahun 1996-2008. RCA dinamis merupakan metode yang digunakan untuk melihat daya saing tersebut. Berdasarkan hasil analisis, dari 16 kelompok produk hanya satu kelompok produk yang kehilangan daya saingnya di pasar ASEAN yaitu produk sayuran sementara produk lain banyak yang berada pada posisi rising star sehingga akan menjadi sangat

dari pasar lain seperti Cina, Indonesia berhasil merebut pasar pada produk plastik dan karet, produk mineral dan alas kaki.

Rifin (2013) menganalisis ekspor kakao Indonesia dengan menggunakan metode RCA dan Almost ldeal Demand System (AIDS). Hasil menunjukkan bahwa Indonesia memiliki keunggulan komparatif biji kakao meskipun tiga negara pesaing memiliki indeks RCA yang lebih tinggi. Sementara itu, biji kakao Indonesia dan Ghana bersifat komplementer. Fakhrudin \& Hasni (2009) menganalisis ekspor produk makanan olahan Indonesia yang prioritas dengan metode indeks komposit yang dikembangkan oleh International Trade Center (ITC). Dari hasil analisis terungkap bahwa pada periode 2003-2007 makanan olahan prioritas tinggi adalah produk ikan, teh dan tembakau.

Dari berbagai penelitian yang disebutkan sebelumnya, belum ada yang menganalisis tentang posisi daya saing ekspor produk makanan olahan ke Timur Tengah dengan metode RCA dinamis. Penelitian Ozcelik \& Erlat (2013) menganalisis berbagai produk Turki ke Uni Eropa, Kathuria (2013) di melihat daya saing produk TPT di India 
dan Bangladesh, Rifin (2013) menganalisis ekspor biji kakao dengan metode RCA dan AIDS, Fakhrudin \& Hasni (2009) menganalisis produk makanan olahan ekspor Indonesia berdasarkan prioritas. Sedangkan Widyasanti (2010) menggunakan RCA dinamis untuk menganalisis berbagai produk ekspor Indonesia dalam kerangka AFTA dan ACFTA.

Beberapa penelitian juga menggambarkan berbagai hambatan yang dihadapi oleh berbagai negara dalam mengekspor pangan maupun makanan olahan. Penelitian Nugroho (2014) meneliti faktor penghambat ekspor kopi Indonesia. Dimana regulasi mengenai Ochtratoxin berdampak pada ekspor kopi Indonesia ke negara eksportir kopi utama, namun dampak tersebut dapat diminimalisir melalui negosiasi bilateral.

Thuong (2017) menganalisis pengaruh Sanitary and Phytosanitary (SPS) terhadap ekspor beras Vietnam menggunakan metode gravitasi. Hasilnya menunjukkan bahwa meskipun PDB, populasi, jarak dan produksi masih merupakan faktor penting, tindakan SPS oleh negara pengimpor memiliki dampak signifikan terhadap ekspor beras Vietnam.
Namun, efek ini menurun saat pendapatan importir meningkat.

Lestari et. al (2013) menganalisis daya saing tuna olahan indonesia di pasar internasional dengan menggunakan RCA dan Competitive Profile Matrix (CPM). Hasilnya tuna olahan Indonesia mempunyai daya saing lebih tinggi bila dibandingkan dengan tuna beku, namun lebih rendah bila dibandingkan dengan tuna segar. Hambatan yang dihadapi eksportir dalam ekspor tuna olahan adalah tingginya tarif impor di negara mitra dan hambatan non tarif seperti mutu, sanitasi, isu lingkungan, keamanan pangan, kesehatan, dan terorisme.

Sementara itu, Ratanamaneichat \& Rakkarn (2013) membahas masalah peraturan impor makanan Indonesia. Indonesia sebagai pasar produk makanan halal terbesar di Asia memandang penting jaminan kualitas produk halal sebagai salah satu strategi keamanan pangan. Persyaratan dan peraturan halal ditekankan pada proses pembuatan halal yang disertifikasi oleh Majelis Ulama Indonesia (MUI).

Dari tulisan Nugroho (2014), Thuong (2017). Lestari et.al (2013) serta Ratanamaneichat \& Rakkarn (2013) dapat disimpulkan bahwa 
ekspor makanan atau produk pangan kerap menemukan hambatan di negara tujuan ekspor, hingga akan memengaruhi kinerja ekspor produk. Oleh karena itu, selain melihat posisi daya saing produk makanan olahan Indonesia ke Timur Tengah, analisis ini juga akan memberikan rekomendasi dalam menghadapi hambatan ekspor produk makanan olahan Indonesia ke Timur Tengah. Rekomendasi kebijakan untuk meningkatkan ekspor produk makanan olahan ke Timur Tengah yang ada dalam analisis ini merupakan hasil analisis strategi dengan menggunakan metode Analytic Hierarchy Process (AHP).

Metode AHP pertama kali diperkenalkan oleh Saaty (1987) merupakan salah satu instrumen yang dinilai cukup efektif dalam membantu para pemangku kebijakan untuk dapat menetapkan prioritas sehingga didapat keputusan terbaik. Metode AHP juga merupakan metode pengambilan keputusan yang paling banyak digunakan dan telah diaplikasikan dalam berbagai bidang.

Dalam AHP terdapat sejumlah opsi alternatif yang dievaluasi dengan menggunakan beberapa variabel atau kriteria. Prinsip kerja AHP adalah berupa simplifikasi dari keputusan yang bersifat kompleks dan tidak terstruktur menjadi elemen-elemen (kriteria dan opsi alternatif). Elemen-elemen tersebut disusun secara hierarki untuk kemudian tingkat kepentingan setiap elemen diberikan skor atau bobot secara subyektif terkait tingkat prioritas dari suatu elemen secara relatif dibandingkan dengan elemen yang lain pada tingkatan yang sama dan juga terkait dengan elemen yang berada pada satu tingkat di atasnya (Marimin, 2004). Oleh karena itu, keandalan analisis dengan menggunakan metode AHP sangat bergantung pada persepsi subyektif manusia yang dianggap sebagai ahli representatif di bidangnya sebagai input utama dalam menentukan prioritas.

Dalam analisis AHP, tahapantahapan yang digunakan antara lain:

\section{a. Decomposition}

Setelah permasalahan didefinisikan, maka perlu dilakukan dekomposisi yaitu memecah persoalan yang utuh menjadi beberapa unsur-unsur yaitu tujuan (goal) dari suatu kegiatan, perumusan kriteria (criteria) untuk memilih prioritas dan identifikasi pilihan-pilihan atau alternatif (options).

\section{b. Comparatif Judgement}

Prinsip ini berarti membuat penilaian prioritas antara dua elemen yang 
dipasangkan pada satu tingkatan tertentu berdasarkan atau berkaitan dengan tingkat yang terdapat di atasnya. Penilaian ini merupakan bagian yang paling penting dalam metode AHP. Hasil penilaian tersebut dapat disajikan melalui matrik pairwise comparison.

c. Synthesis of Priority, melakukan sintesis terhadap prioritas.

Adapun untuk memperoleh input dari AHP maka dilakukan Focus Group Discussion (FGD) dengan mengundang perwakilan dari para asosiasi dan pelaku usaha terkait guna memperoleh bobot prioritas strategi untuk mengurangi hambatan ekspor makanan olahan ke Timur Tengah.

\section{HASIL DAN PEMBAHASAN}

Analisis penentuan daya saing ekspor produk makanan olahan Indonesia ke Timur Tengah dilakukan terhadap sepuluh negara yang memiliki nilai perdagangan terbesar yaitu; Arab Saudi, Uni Emirat Arab, Mesir, Oman, Bahrain, Qatar, Kuwait, Iran, Jordania, dan Lebanon.

\section{Posisi Daya Saing Produk Makanan Olahan Indonesia di Arab Saudi}

Pertumbuhan ekonomi Arab Saudi yang ditopang dari pendapatan penjualan minyak mengalami perlambatan sejak tahun 2008 seiring dengan krisis keuangan global dan penurunan harga komoditas dunia. Defisit anggaran akibat merosotnya harga minyak dunia, mendorong Kerajaan Arab Saudi untuk mengembangkan alternatif pendapatan lain diluar minyak bumi. Nilai impor makanan olahan Arab Saudi dari dunia pada periode 2012-2016 mengalami peningkatan $3,5 \%$ per tahun.

Hasil perhitungan RCA dinamis terdapat 17 produk makanan olahan Indonesia yang diekspor ke Arab Saudi potensial untuk dikembangkan (Gambar 2). Dari 17 produk terdapat tiga produk yang masuk dalam kuadran I yaitu pada saat pertumbuhan pangsa pasar Indonesia dan Arab Saudi positif yaitu Food preparation (HS 210690), Pineapple juice (HS 200949) dan Soya sauce (HS 210310). Dari ketiga produk tersebut dapat diklasifikasikan menjadi dua bagian yaitu rising star, untuk komoditi (1), yang terjadi pada saat peningkatan pangsa pasar Indonesia lebih tinggi dibandingkan peningkatan pangsa pasar Arab Saudi dan Lagging Opportunity (LagO) untuk komoditi (13 dan 17), yang terjadi pada saat peningkatan pangsa pasar Indonesia lebih rendah dibandingkan peningkatan pangsa pasar Arab Saudi. 


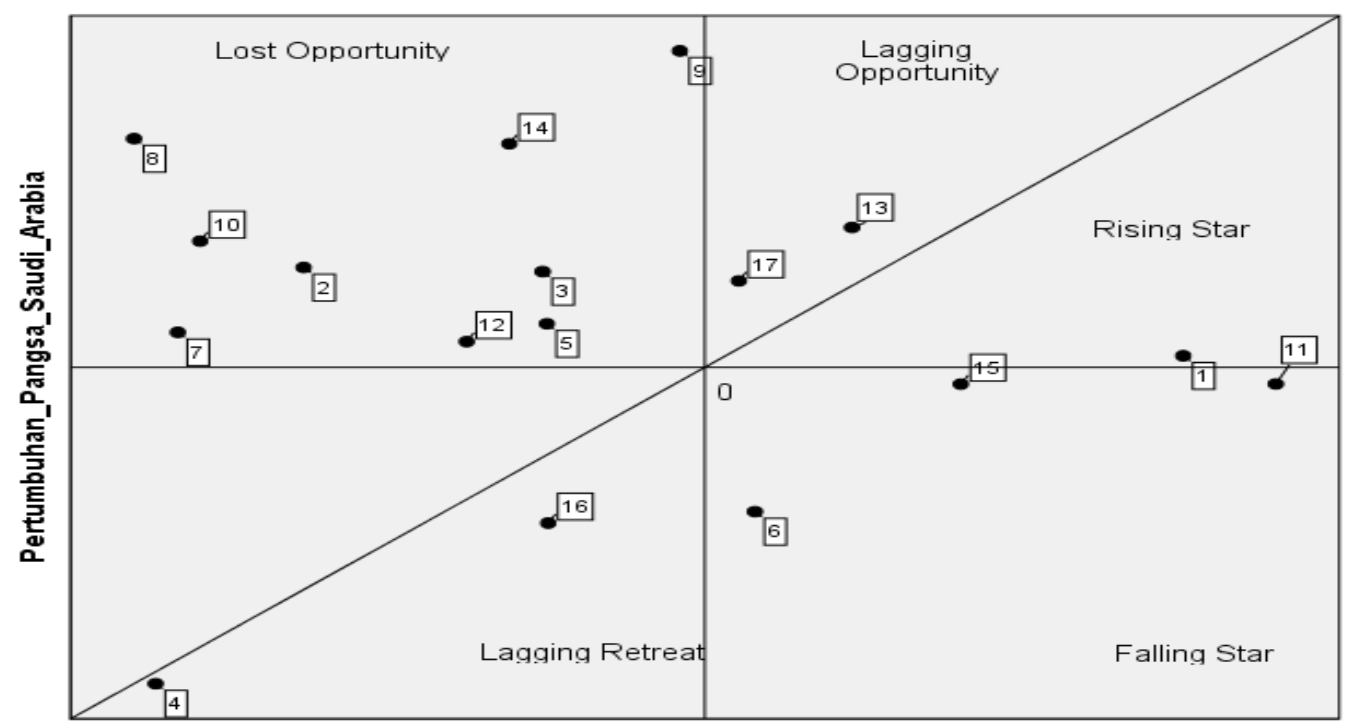

Pertumbuhan_Pangsa_Indonesia

\section{Gambar 2. Posisi Daya Saing Ekspor Produk Makanan Olahan Indonesia ke Arab Saudi, 2011-2015}

Keterangan:

1. HS 210690 (food prepartions)

2. HS 190590 (bread, pastry, biscuits and other baker's...)

3. HS 190531 (sweet biscuits)

4. HS 180620 (Chocolate and other food preparations containg cocoa...)

5. HS 210390 (preparations for sauces and prepared sauces...)

6. HS 190532 (waffles and wafers)

7. HS 200990 (mixture of fruit juice...)

8. HS 220210 (waters, include mineral and aerated...)

9. HS 190190 (malts extract...)

10. HS 190210 (Uncooked pasta, not stuffed or otherwise prepared...)

11. HS 190210 (Uncooked pasta, not stuffed or otherwise prepared...)

12. HS 200811 (Groundnuts, prepared preserved)

13. HS 200949 (Pineaplle juice, unfermented...)

14. HS 180610 (cocoa poedwer, sweetened)

15. HS 170410 (Chewin gum...)

16. HS 190230 (pasta, cooked or otherwised prepared)

17. HS 210310 (soya sauce)

Dalam Gambar 2, terlihat bahwa produk yang dikategorikan sebagai peningkatan dan Indonesia dapat mengambil keuntungan dengan rising star adalah Food preparation (HS 210690). Produk ini dikategorikan sebagai rising star karena peningkatan pangsa Indonesia untuk produk ini di pasar Arab Saudi cukup besar yaitu $167,69 \%$, sedangkan pangsa impor produk ini terhadap impor total produk makanan Arab Saudi juga mengalami peningkatan sebesar 5,38\%. Hal ini terjadi karena dari sisi permintaan impor produk ini mengalami menambah pangsa hampir dua kali lipatnya. Peningkatan pangsa ini diakibatkan oleh peningkatan ekspor produk food preparation ini sebanyak lebih dari tiga kali lipatnya pada periode 2011 dan 2015 sehingga mengakibatkan daya saing produk Food preparation Indonesia di pasar Arab Saudi mengalami peningkatan.

Dua produk yang termasuk ke dalam LagO adalah Pineapple juice 
(HS 200949) dan Soya sauce (HS 210310). Dua produk ini belum maksimal merebut peningkatan pangsa pasar Arab Saudi untuk produk ini terhadap impor total, walaupun pangsa pasar produk Indonesia mengalami peningkatan. Pada pineapple juice, peningkatan pangsa pasar Arab Saudi sebesar $65,7 \%$ sementara peningkatan pangsa pasar Indonesia hanya sebesar $51,6 \%$. Pada soya sauce peningkatan pangsa pasar Arab Saudi sebesar $40,6 \%$ sedangkan pangsa pasar Indonesia meningkat hanya sebesar $11,89 \%$ yang mengakibatkan daya saing kedua produk ini mengalami penurunan di pasar Arab Saudi.

Pada kategori kedua adalah yang berada pada kuadran II yaitu pada saat pangsa pasar Arab Saudi mengalami peningkatan namun pangsa pasar Indonesia mengalami penurunan atau disebut sebagai Lost Opportunity (LO). Penurunan pangsa pasar ini lebih disebabkan oleh peningkatan ekspor produk tersebut tidak sebesar dibandingkan ekspor total produk makanan. Pada kategori ini terdapat sembilan produk yaitu bread (HS 190590), sweet biscuits (HS 190531), sauces and prepared sauces (HS 210390), mixed fruit juices (HS 200990), mineral waters (HS 220210), malt extract (HS 190190), nuts and other seed (HS 200819), groundnuts (HS 200811) dan cocoa powder sweetened (HS 180610). Pada produk ini, Indonesia kehilangan kesempatan dari peningkatan permintaan pangsa pasar Arab Saudi sehingga menyebabkan daya saing produk Indonesia mengalami penurunan.

Pada kategori berikutnya pangsa pasar Indonesia mengalami peningkatan namun pangsa pasar Arab Saudi mengalami penurunan yang disebut sebagai falling star. Pada kategori ini terdapat tiga produk yaitu waffles and wafers (HS 190532), uncooked pasta (HS 190219) dan chewing gum (HS 170410). Penurunan pangsa pasar Arab Saudi dapat disebabkan oleh peningkatan impor produk tersebut tapi peningkatannya tidak sebesar peningkatan total impor produk makanan Arab Saudi. Pada periode 2011-2015, peningkatan total impor produk makanan Arab Saudi sebesar $28 \%$ sedangkan peningkatan impor waffles and wafers hanya sebesar $21,3 \%$, uncooked pasta sebesar $27,2 \%$ dan chewing gum sebesar 27,2\%. Dari segi daya saing, pada kategori ini daya saing Indonesia mengalami peningkatan. Kategori terakhir adalah leading retreat yaitu kedua pangsa 
pasar baik Indonesia dan Arab Saudi mengalami penurunan. Produk yang masuk ke dalam kategori ini adalah Chocolate and other food preparation (HS 180620) dan Pasta cooked (HS 190230).

\section{Posisi Daya Saing Produk Makanan Olahan Indonesia di Uni Emirat Arab}

Pada tahun 2015, pertumbuhan ekonomi Uni Emirat Arab mencapai $3,4 \%$, menurun dibandingkan dengan pertumbuhan tahun 2014 yang mencapai 4,6\% , dan diperkirakan ratarata pertumbuhan ekonomi UAE sebesar 2,5\% sepanjang 2016-2018 (World Bank, 2016). Nilai impor makanan olahan Uni Emirat Arab dari dunia pada periode 2012-2016 mengalami peningkatan 3,0\%/tahun.

Pada periode 2012 - 2015, terdapat puluhan produk makanan olahan yang diekspor ke Uni Emirat Arab (UEA). Dari analisis daya saing menggunakan RCA Dinamis, diperoleh sepanjang periode 2012-2015, terdapat 20 produk makanan olahan Indonesia yang diekspor ke UEA dan sangat potensial untuk dikembangkan. Hal ini dapat dilihat bahwa, terdapat 11 kelompok produk makanan yang dapat dikategorikan sebagai rising star dan masuk dalam kuadran I, yakni: (1) Nonalcoholic beverages (HS 220290); (2)
Waffles and wafers (HS 190532); (3) Extracts, essences and concentrates, of coffee (HS 210111); (4) Food preparations (HS 210420); (5) Uncooked pasta (HS 190219); (6) Bread, pastry, cakes (HS 180632); (7) Chocolate and other preparations containing cocoa (HS 200799); (8) Jams (HS 180690); (9) Chocolate (HS 180690); (10) Sweet biscuits (HS 190531); dan (11) Crab (HS 160510). Produk-produk makanan olahan yang berasal dari Indonesia ini, memiliki pertumbuhan pangsa pasar produk Indonesia ke UEA lebih besar bila dibandingkan pertumbuhan pangsa impor produk ini terhadap total impor makanan UEA.

Produk makanan olahan yang memiliki daya saing dan sangat potensial dikembangkan adalah produk Non-alcoholic beverage (HS 220290), hal ini dapat dilihat dari pertumbuhan pangsa pasar Indonesia untuk produk ini di pasar UEA sangat besar yaitu $3055,2 \%$, sedangkan pertumbuhan pasar impor produk ini terhadap impor total produk makanan UEA juga mengalami peningkatan sebesar $88,6 \%$. Begitu juga dengan 10 produk makanan lainnya, pertumbuhan pangsa pasar produk Indonesia di pasar UEA diatas $100 \%$ yakni; Waffles and wafers 
(HS 190532); Extracts, essences and concentrates, of coffee (HS 210111); Food preparations (HS 210420); Uncooked pasta (HS 190219); Bread, pastry, cakes (HS 180632); Chocolate and other preparations containing cocoa (HS 200799); sedangkan produk lainnya pertumbuhan pertumbuhan pangsa pasar produk Indonesia di pasar UEA dibawah $100 \%$.

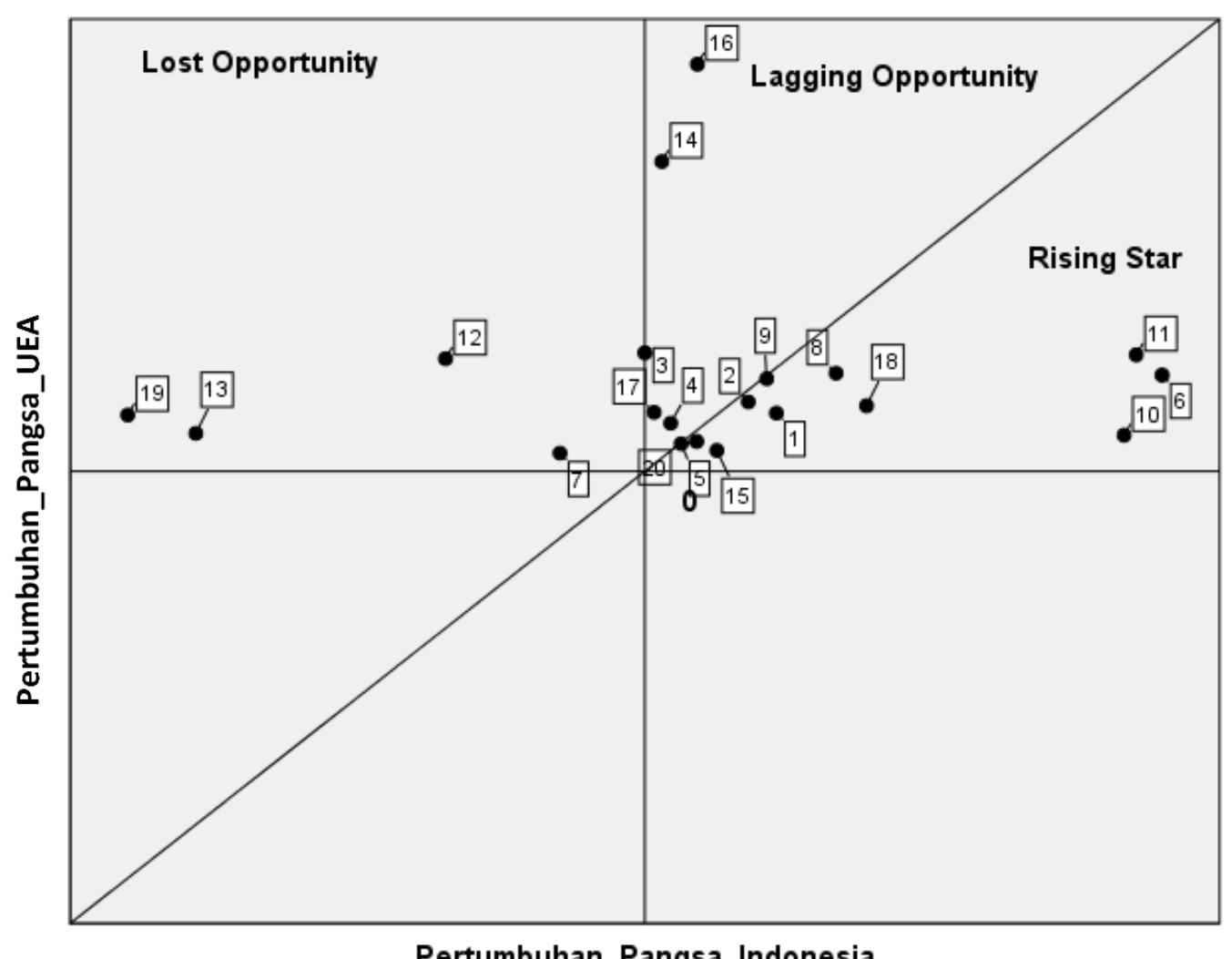

\section{Gambar 3. Posisi Daya Saing Ekspor Produk Makanan Olahan Indonesia ke Uni Emirat Arab, 2011-2015}

Keterangan:

1. HS 190590 (bread, pastry, biscuits and other baker's...)

2. HS 180690 (Chocolate and other preparation containing cocoa)

3. HS 190190 (Malt extract)

4. HS 210390 (preparations for sauces and prepared sauces...)

5. HS 190531 (sweet biscuits)

6. HS 220290 (Non-alcoholic beverages)

7. HS 160414 (Prepared or preserved tunas, skipjack and Atlantic bonito...)

8. HS 190219 (Uncooked pasta, not stuffed or otherwise)

9. HS 180632 (Bread, pastry, cakes)
10. HS 210111 (extracts, essences and concentrates...)

11. HS 190532 (waffles and wafers)

12. HS 200811 (groundnuts, prepared preserved)

13. HS 170410 (Chewing gum, wether or not sugar)

14. HS 200820 (pineapples, prepared or preserved wether or not containing added sugar...)

15. HS 200799 (jams, jellies, marmalades...)

16. HS 190490 (Cereals)

17. HS 190230 (pasta, cooked or otherwised prepared)

18. HS 210420 (food preparations consisting of finely...)

19. HS 180610 (cocoa powder, sweetened)

20. HS 160510 (Crab, prepared or preserved) 
Hasil RCA Dinamis juga 21,92\%. Padahal Indonesia memiliki menunjukkan bahwa selain rising star, potensi sebagai pemasok makanan terdapat kategori posisi daya saing olahan berbahan dasar buah-buah LagO pada kuadran I. LagO mengindikasikan bahwa produk-produk makanan olahan yang masuk dalam wilayah ini tidak dapat mengambil kesempatan dari peningkatan pasar produk ini terhadap impor total, walaupun pangsa pasar produk tersebut di Indonesia juga mengalami peningkatan, atau dengan kata lain pertumbuhan pangsa impor produk tersebut terhadap total produk makanan lebih besar bila dibandingkan pertumbuhan pangsa ekspor produk Indonesia.

Terdapat empat produk makanan olahan yang masuk dalam kategori LagO yaitu: (1) Cereals (HS 190490); (2) Preparations for sauces and prepared sauces (HS 210390); (3) Pineapples (HS 200820); (4) Pasta (HS 190230). Produk Cereals merupakan produk makanan olahan yang pertumbuhan pangsa di UEA sebesar $375,38 \%$ sedangkan pertumbuhan pangsa pasar Indonesia untuk cereals hanya sebesar 68,09\%, begitu juga dengan pineapples (HS 210390) pertumbuhan pasar UEA sebesar $285,51 \%$ namun pertumbuhan pangsa pasar Indonesia hanya sebesar

tropika, perlunya identifikasi kebutuhan pasar di negara-negara konsumen oleh perwakilan dagang Indonesia perlu dilakukan untuk menentukan strategi dan pemetaan kemampuan produk yang dimiliki untuk ekspor. Selain itu, terdapat produk Preparations for sauces and prepared sauces (HS 210390) dan Pasta (HS 190230), dimana keduanya adalah produk makanan dalam bentuk pasta. Ketidakmampuan kedua produk ini memenangkan pangsa pasar di UEA, diduga produk sejenis dari negara pesaing (Eropa) lebih unggul. Karena ketidakmampuan keempat produk ini memanfaatkan peningkatan pangsa pasar di negara tujuan ekspor, menyebabkan daya saing keempat produk ini mengalami penurunan di pasar UEA.

Kategori berikutnya yang perlu dicermati adalah pada kuadran II. Kuadran di wilayah ini menunjukkan bahwa pangsa pasar di negara tujuan ekspor mengalami peningkatan, namun pangsa pasar produk sejenis di negara produsen (eksportir) mengalami penurunan, kondisi ini disebut kategori LO. Ada lima produk makanan olahan 
Indonesia yang di ekspor ke UEA masuk dalam kategori LO, yakni; (1) Malt extract (HS 190190); (2) Prepared or Preserved tunas (HS 160414); (3) Groundnuts (HS 200811); (4) Chewing gum (HS 170410); dan (5) Cocoa powder (HS 180610). Produk makanan olahan yang paling besar penurunan pangsa pasar ekspor ke UEA adalah Cocoa powder sebesar 84,99\%, sedang peningkatan pangsa pasar di negara UEA sebesar 51,83\%, sedangkan untuk produk makanan olahan pada kelompok Malt extract, pangsa pasar ekspor Indonesia mengalami penurunan sebesar $0,02 \%$, namun peningkatan pertumbuhan pangsa pasar di UEA sebesar $109,14 \%$. Kondisi menyebabkan daya saing produk makanan olahan yang masuk dalam kategori ini mengalami penurunan daya saing, karena produk makanan Indonesia kehilangan kesempatan untuk menangkap peluang pasar potensial dari peningkatan pangsa pasar UEA. Perlu dicermati lebih mendalam, bagaimana pengaruh produk sejenis di pasar UEA, secara umum produk-produk yang masuk dalam kategori ini merupakan produk yang memiliki potensi baik dari bahan baku dan industri nasional.

\section{Posisi Daya Saing Produk Makanan Olahan Indonesia di Mesir}

Mesir merupakan negara yang strategis di kawasan Timur Tengah. Sekitar 55\% dari total PDB Mesir pada tahun 2016 berasal dari sektor jasa. Selain sektor jasa, industri manufaktur juga memegang peranan penting bagi perekonomian Mesir dengan pangsa terhadap PDB mencapai 33\%. Permintaan impor makanan olahan Mesir dari dunia mengalami pelambatan $0,03 \%$ pertahun selama periode 2012-2016.

Berdasarkan analisis RCA Dinamis diperoleh bahwa terdapat empat produk makanan olahan yang potensial untuk dikembangkan dan diekspor. Produk makanan olahan yang masuk dalam kelompok Waffles and Wafers (HS 190532) memiliki potensi amat menjanjikan di masa depan dalam konteks perdagangan Indonesia dan Mesir. Hal ini dapat dilihat dari periode 2011 - 2015, produk tersebut masuk dalam kategori rising star. Dimana pertumbuhan pangsa pasar Indonesia untuk produk tersebut ke pasar Mesir sebesar $810 \%$, sedangkan pertumbuhan pangsa pasar Mesir untuk produk tersebut terhadap total impor produk makanan hanya $24 \%$. 
Sehingga dalam periode berikutnya Indonesia dapat meningkatkan pangsa pasarnya lebih dari delapan kali dari kondisi sebelumnya. Pada periode ini, menunjukkan bahwa produk Waffles and Wafers memiliki daya saing yang baik dan bahkan cenderung meningkat. Permintaan yang tinggi ini harus direspon dengan baik oleh produsen Indonesia, untuk memberikan kualitas produk dan kontinuitas, serta keragaman produknya.

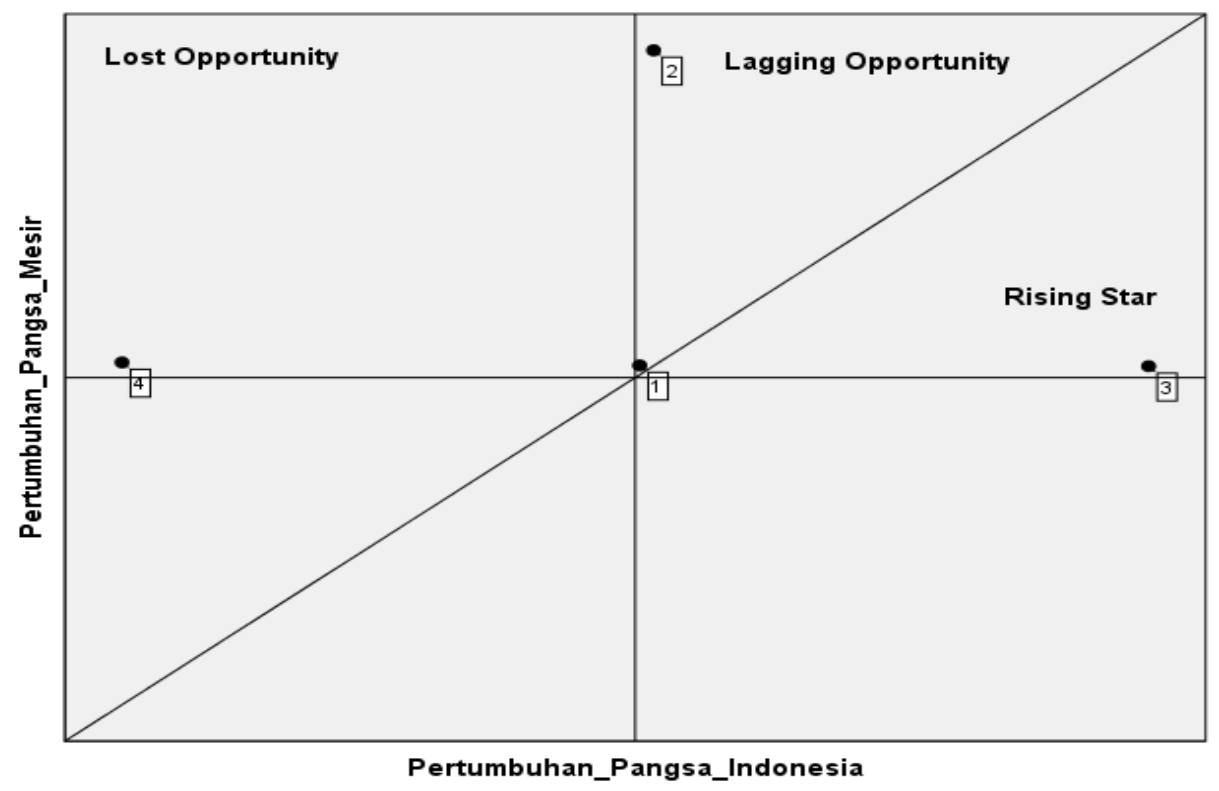

Gambar 4. Posisi Daya Saing Ekspor Produk Makanan Olahan Indonesia ke Mesir, 2011-2015

Keterangan:

1. HS 190593 (Bread, pastry, cakes, biscuits and other bakers' wares, whether or not containing cocoa; communion ...)

2. HS 200949 (Pineapple juice, unfermented, Brix value $>20$ at $20^{\circ} \mathrm{C}$, whether or not containing added sugar ...)

3. HS 190532 (waffles and wafers)

4. HS 160414 (Prepared or preserved tunas, skipjack and Atlantic bonito...)

Dua produk makanan olahan Indonesia yang diekspor ke Mesir, masuk kategori LagO pada kuadran I adalah Bread (HS 190590) dan Pineapple Juice (HS 200949). Kedua produk ini secara umum, belum mampu memenuhi pertumbuhan pangsa pasar kedua produk tersebut di pasar Mesir, hal ini bisa dilihat untuk Pineapple Juice pertumbuhan pangsa pasar Indonesia sebesar 28,8\% sedang pertumbuhan pangsa pasar produk tersebut terhadap pangsa pasar total produk makanan sebesar $696 \%$. Artinya ada permintaan yang cukup tinggi dari produk Pineapple Juice yang belum mampu dipenuhi oleh Indonesia. Selain itu, produk kedua yang masuk kategori ini 
adalah Bread (HS 190590). Pertumbuhan pangsa pasar Indonesia hanya sebesar $6,8 \%$, sedangkan pangsa pasar pertumbuhan produk tersebut terhadap total impor makanan olahan Mesir sebesar 25,8\% (20112015). Kondisi ini jika tidak diantisipasi dengan meningkatkan kemampuan Indonesia untuk memenuhi pasar Mesir, maka akan mengakibatkan daya saing produk ini akan mengalami penurunan di pasar Mesir.

Produk makanan olahan Indonesia yang masuk kategori LO pada kuadran II adalah Prepared or Preserved tunas (HS 160414). Produk ini mengalami penurunan daya saing, dikarenakan penurunan pangsa pasar produk tersebut di pasar Indonesia, namun disisi lain adanya peningkatan pertumbuhan pangsa pasar pada pasar Mesir. Penurunan pangsa pasar ini disebabkan oleh penurunan pangsa pasar produk tersebut di pasar Indonesia sebesar $64,6 \%$, namun disisi lain pertumbuhan pangsa pasar Mesir sebesar $32,2 \%$. Artinya Indonesia tidak mampu memenuhi peningkatan permintaan produk tersebut di pasar Mesir, malah sebaliknya adanya penurunan ekspor produk tersebut ke Mesir.

\section{Posisi Daya Saing Produk Makanan} Olahan Indonesia di Oman

Seperti negara penghasil minyak lainnya, Oman juga terdampak penurunan harga minyak dunia yang menyebabkan Oman mengalami defisit anggaran sebesar USD 11,5 miliar, atau sekitar 19\% dari PDB. Pengembangan sektor ekonomi lainnya juga telah dilakukan oleh pemerintah Oman dengan melakukan diversifikasi, industrialisasi dan privatisasi dengan tujuan mengurangi ketergantungan pada perdagangan minyak sampai dengan 9\% pada tahun 2020. Pada periode 2012-2016, permintaan impor makanan olahan Oman dari dunia meningkat 5,3\% per tahun.

Produk Sweet Biscuits (HS 190531) dan Waffles and Wafers (HS 190532) merupakan dua produk makanan olahan dari Indonesia yang memiliki prospek untuk terus dikembangkan di pasar Oman. Hal ini, dapat dilihat dari periode 2011 - 2015 dengan menggunakan analisis RCA Dinamis, menunjukkan Sweet Biscuits dan Waffles and Wafers masuk dalam kategori rising star. Dimana pangsa pasar dari produk tersebut baik di negara eksportir dan importir samasama mengalami peningkatan. 


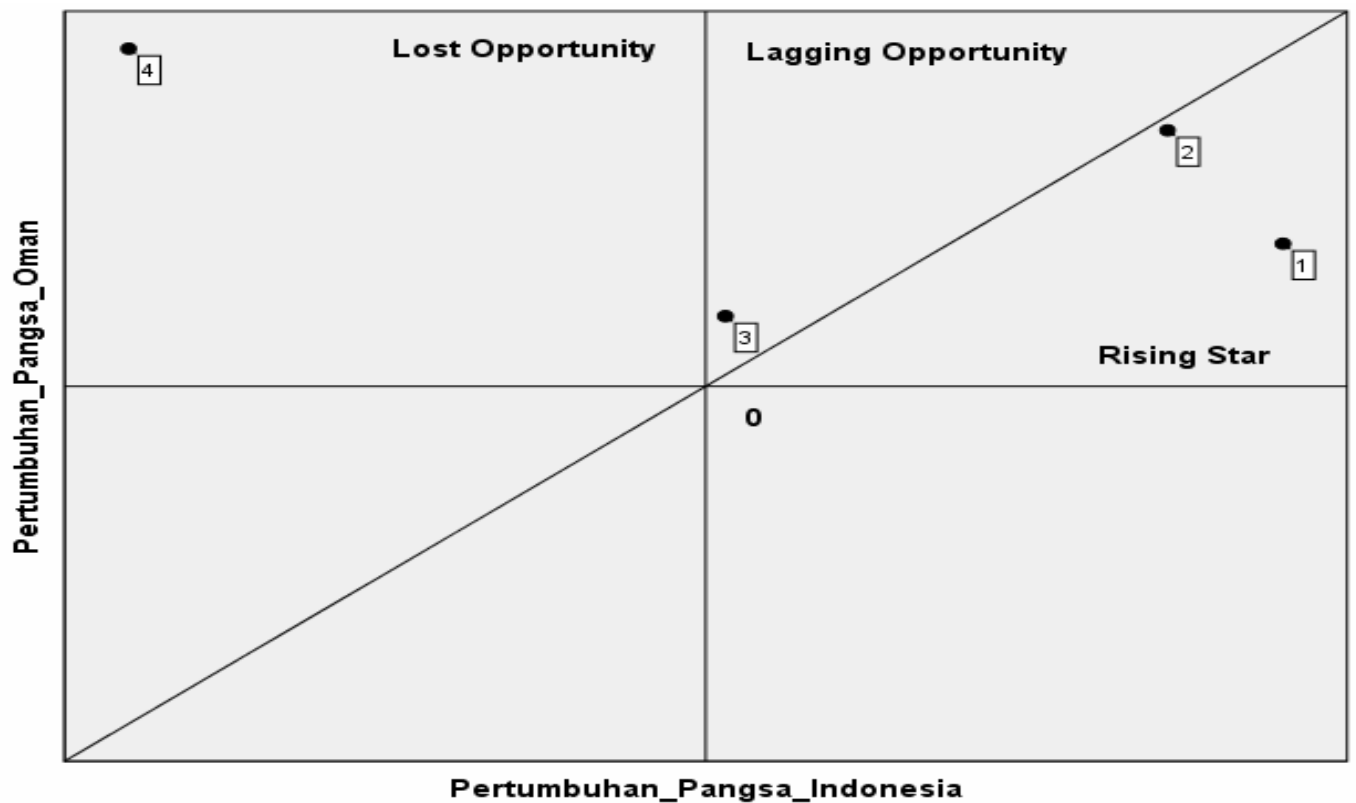

\section{Gambar 5. Posisi Daya Saing Ekspor Produk Makanan Olahan Indonesia ke Oman, 2011-2015}

Keterangan:

1. HS 190531 (sweet biscuits)

2. HS 190532 (waffles and wafers)

3. HS 190590 (bread, pastry, biscuits and other baker's...)

4. HS 160414 (prepared or preserved tunas, skipjack and atalntic bonito...)

Tercatat bahwa pertumbuhan produk Sweet Biscuits dan Waffles and pangsa pasar produk Sweet Biscuits Wafers Indonesia memiliki daya saing dan Waffles and Wafers di pasar yang sangat baik, bila dibandingkan Indonesia masing-masing sebesar dengan produk sejenis dari negara $236,45 \%$ dan $136,29 \%$ sedangkan pesaing.

pertumbuhan pangsa pasar Oman

Produk makanan olahan dengan untuk produk tersebut adalah masing kelompok Breads (HS 190590) juga masing sebesar $45,38 \%$ dan $81,49 \%$. memiliki potensi untuk dikembangkan Artinya ada kesempatan untuk di pasar ekspor Oman. Hal ini meningkatkan pangsa pasar produk ditunjukkan dengan adanya peningWaffles and Wafers Indonesia katan pertumbuhan pangsa pasar di sebanyak dua-tiga kali selama periode 2011 - 2015. Hal ini menunjukkan permintaan yang tinggi dari Oman, mampu dipenuhi oleh produk makanan olahan Indonesia. Dengan demikian kedua negara, baik Indonesia sebagai produsen dan Oman sebagai Importir. Namun perlu menjadi catatan, bahwa produk Breads masuk dalam kategori LagO, dimana pertumbuhan ekspor 
negara produsen seperti Indonesia tidak sebesar pertumbuhan impor dari total pangsa pasar makanan olahan di Oman. Produsen Indonesia belum mampu memanfaatkan momentum akibat adanya peningkatan pangsa pasar di Oman (2011 - 2015). Jika kondisi ini berlangsung cukup lama, akan menyebabkan produk Breads Indonesia mengalami penurunan daya saing, karena pasarnya digantikan atau digeser oleh negara pesaing lainnya.

Produk lain yang menjadi perhatian adalah Prepared or Preserved tunas (HS 160414), produk makanan olahan ini masuk dalam kategori LO pada kuadran II. Hal ini mengindikasikan bahwa secara umum pangsa pasar Indonesia terhadap produk Prepared or Preserved tunas mengalami penurunan, namun disisi lain pangsa pasar impor produk sejenis terhadap total makanan olahan Oman meningkat drastis. Kondisi ini menunjukkan Indonesia kehilangan kesempatan untuk meningkatkan ekspornya ke negara Oman. Kondisi ini terjadi, disebabkan produk Prepared or Preserved tunas mengalami penurunan daya saing. Keberhasilan produk pesaing memberikan kualitas yang diinginkan konsumen/pasar di Oman diperkirakan

menjadi

penyebab penurunan daya saing produk Indonesia.

\section{Posisi Daya Saing Produk Makanan Olahan Indonesia di Bahrain}

Kontribusi perdagangan terhadap perekonomian Bahrain cenderung masih besar. Pada tahun 2016, kontribusi total perdagangan terhadap PDB mencapai 66,8\%. Pada tahun sebelumnya, porsi perdagangan mampu mencapai $77,3 \%$ terhadap total PDB. Tren permintaan impor makanan olahan Bahrain dari dunia mengalami pelambatan $2,0 \%$ per tahun selama periode 2012-2016.

Terdapat empat produk yang potensial untuk dikembangkan bagi Indonesia di negara Bahrain. Keempat produk tersebut dapat dikelompokkan ke dalam tiga kelompok. Kelompok pertama yaitu rising star untuk produk Waffles and Wafers (HS 190532), pada produk ini pangsa ekspor Indonesia mengalami peningkatan yang lebih besar (407\%) dibandingkan dengan pangsa impor Bahrain yaitu sebesar $171 \%$. Hal ini menunjukkan bahwa Indonesia dapat memanfaatkan peningkatan permintaan produk ini di Bahrain sehingga daya saing produk ini mengalami peningkatan. 


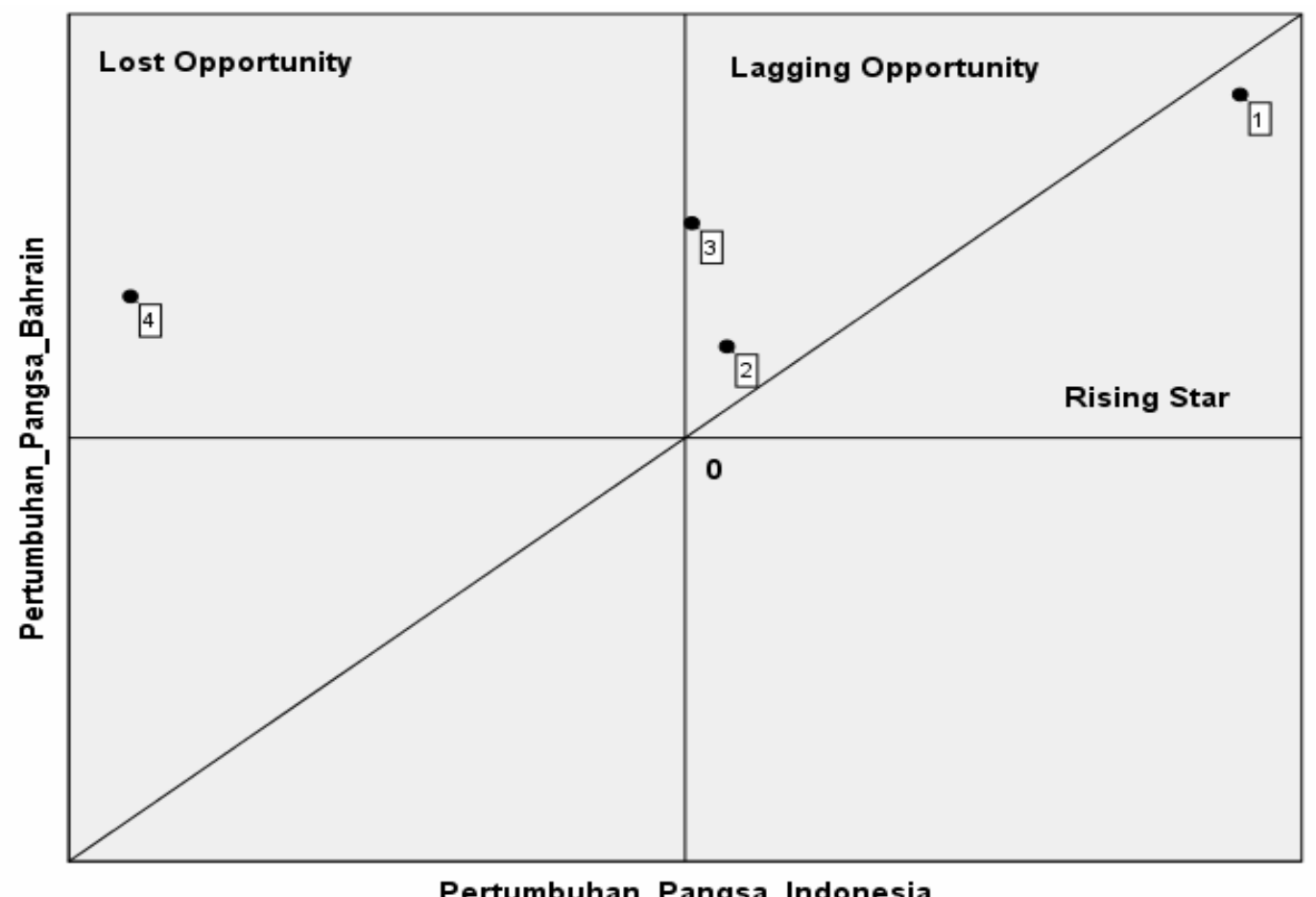

\section{Gambar 6. Posisi Daya Saing Ekspor Produk Makanan Olahan Indonesia ke Bahrain, 2011-2015}

Keterangan:

1. HS 190532 (waffles and wafers)

2. HS 190590 (bread, pastry, biscuits and other baker's...)

Kelompok kedua adalah yang termasuk dalam LagO. Produk yang masuk dalam kelompok ini adalah Bread (HS 190590) dan Sauces and prepared sauces (HS 210390). Pada kedua produk ini baik pangsa Indonesia maupun Bahrain mengalami peningkatan namun peningkatan pangsa Bahrain lebih tinggi dibandingkan Indonesia sehingga mengakibatkan menurunnya daya saing Indonesia untuk kedua produk tersebut. Hal ini menunjukkan bahwa kedua produk Indonesia ini belum mampu memanfaatkan secara
3. HS 210390 (preparations for sauces and prepared sauces..) 4. HS 190531 (sweets biscuits)

maksimal kenaikan permintaan produk tersebut di Bahrain.

Produk Sweet biscuits (HS 190531) termasuk kategori LO karena pangsa pasar Indonesia mengalami penurunan sedangkan pangsa pasar Bahrain untuk produk ini mengalami peningkatan. Pada produk ini ekspor mengalami peningkatan pada periode 2011-2015 namun peningkatannya lebih rendah dibandingkan peningkatan ekspor total Indonesia sehingga menyebabkan pangsa mengalami penurunan dan daya saing juga terjadi penurunan. 
Posisi Daya Saing Produk Makanan Olahan Indonesia di Qatar

Pendapatan Qatar mayoritas berasal dari minyak bumi dan gas alam, pada tahun 2016 Qatar membukukan PDB sebesar USD 152,47 miliar, naik 2,2\% dibanding tahun sebelumnya. Selama periode 2012-2016 permintaan impor produk makanan olahan Qatar dari dunia melambat $1,2 \%$ per tahun.

Produk makanan olahan Indonesia yang memiliki prospek dan daya saing yang sangat baik untuk dikembangkan dan diekspor ke negara Qatar pada periode 2011 - 2015 berdasarkan analisis RCA Dinamis adalah; (1) Pasta, cooked or otherwise prepared (HS 190230); (2) Nonalcoholic beverage (HS 220290); dan (3) Preparations for sauces (HS 210390). Ketiga produk tersebut masuk dalam kategori rising star pada kuadran I dan memiliki pertumbuhan pangsa pasar yang positif untuk pasar di Indonesia dan jauh lebih besar bila dibandingkan pertumbuhan pangsa pasar impor terhadap total makanan olahan di pasar Qatar.

Dari tiga produk yang masuk dalam kategori rising star produk Pasta, cooked or otherwise prepared (HS 190230) memiliki potensi dan daya saing yang sangat baik, dimana produk ini memiliki daya saing yang sangat bagus di Qatar. Hal ini dapat diliat dari nilai pangsa pasar Indonesia terhadap produk Pasta, cooked or otherwise prepared adalah sebesar $798,12 \%$ sedangkan pertumbuhan pangsa pasar produk tersebut terhadap total impor produk makanan olahan Qatar hanya $137,57 \%$. Hal ini menunjukkan dari sisi permintaan impor di negara tujuan, produk in mengalami peningkatan dan Indonesia dapat mengambil keuntungan dengan menambah pangsa pasar sampai hampir delapan kali.

Begitu juga untuk Non-alcoholic beverage, produk ini menunjukkan hal yang sama bahwa peningkatan pangsa pasar dapat dicapai sebesar dua sampai delapan kali lipat pada periode 2011 - 2015. Produk Preparations for sauces, walaupun peningkatan kapasitas pangsa pasar tidak sebesar dari tiga produk lainnya di rising star, namun juga memiliki potensi yang sangat baik untuk digarap dan dioptimalkan, karena memiliki daya saing yang tinggi.

Empat dari sembilan produk yang diekspor ke Qatar masuk dalam kategori LO pada kuadran II adalah; (1) Prepared foods obtained by swelling or 
roasting cereals (HS 190410); (2) mengalami peningkatan selama Sweet biscuits (HS 190531); (3) Cocoa periode 2011-2015. Kelompok produk Powder (HS 18160); dan (4) yang penurunan pertumbuhan pangsa Pineapples (HS 200820). Keempat pasarnya sangat besar bila produk ini menunjukkan pertumbuhan dibandingkan dengan empat produk pangsa pasar Indonesia, sedangkan lainnya adalah Prepared foods pangsa pasar impornya terhadap impor obtained by swelling or roasting cereals total makanan di pasar Qatar (HS 190410) sebesar 72,2\%.

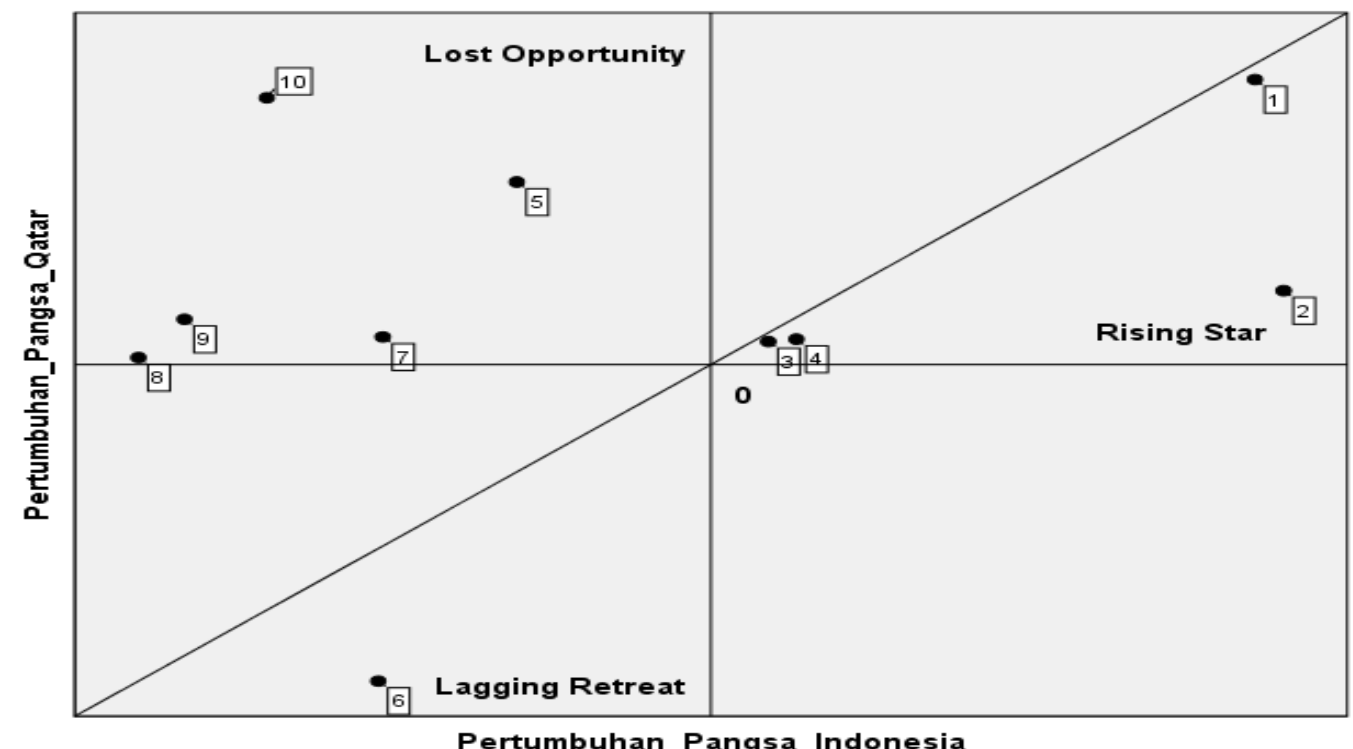

\section{Gambar 7. Posisi Daya Saing Ekspor Produk Makanan Olahan Indonesia ke Qatar, 2011-2015}

Keterangan:

1. HS 190230 (pasta, cooked or otherwised prepared)

2. HS 210390 (preparations for sauces and prepared sauces..)

3. HS 220290 (non-alcoholic beverage...)

4. HS 190590 (Bread, pastry, cakes, biscuits and other baker's wares...)

5. HS 210690 (food prepartions)

6. HS 200820 (pineapples, prepared or preserved wether or not containing added sugar...)

7. HS 190410 (prepared foods obtained by swelling or roasting cereals or cereal products...)

8. HS 190531 (sweet biscuits)

9. HS 180610 (cocoa powder, sweetened)

Produk potensial lain yang perlu diperhatikan untuk pasar Qatar adalah Food Preparations (HS 210690), produk ini mengalami penurunan daya saing selama periode 2011-2015. Produk ini berada pada kategori leading retreat, dimana pertumbuhan pangsa pasar kedua negara produsen dan importir sama-sama mengalami penurunan. Berdasarkan analisis RCA dinamis, diperoleh penurunan pangsa pasar Indonesia sebesar 41,96\% lebih 
besar dari penurunan pangsa pasar Qatar sebesar $12,4 \%$. Pada kondisi ini juga perlu diperhatikan, bahwa penurunan permintaan untuk produk Food Preparations di Qatar, harus dicermati dengan mencari alternatif produk lain yang bisa dipromosikan kembali. Disamping itu juga bisa meningkatkan volume ekspor produkproduk yang masuk pada kategori rising star.

\section{Posisi Daya Saing Produk Makanan Olahan Indonesia di Lebanon}

PDB Lebanon mencapai USD 47,54 miliar pada tahun 2016. Struktur pembentuk PDB utama adalah dari sektor jasa sebesar $69,4 \%$, industri sebesar $25 \%$ dan sektor pertanian sebesar $5,7 \%$. Permintaan produk makanan olahan Lebanon dari dunia rata-rata tumbuh $4,0 \%$ per tahun di 2012-2016.

Di Lebanon terdapat tiga produk ekspor Indonesia yang potensial dan dapat dikategorikan ke dalam dua kelompok. Kelompok pertama adalah rising star yaitu untuk dua produk yaitu Sweet buiscuits (HS 190531) dan extract of coffee (HS 210111). Kedua produk ini peningkatan pangsa Indonesia lebih besar dibandingkan peningkatan pangsa Lebanon sehingga mengakibatkan peningkatan daya saing (2011-2015). Peningkatan pangsa Indonesia yang besar ini disebabkan oleh peningkatan ekspor yang cukup signifikan, pada Sweet biscuits mengalami peningkatan sebesar $300 \%$ sedangkan extract of coffee sebesar $1.036 \%$.

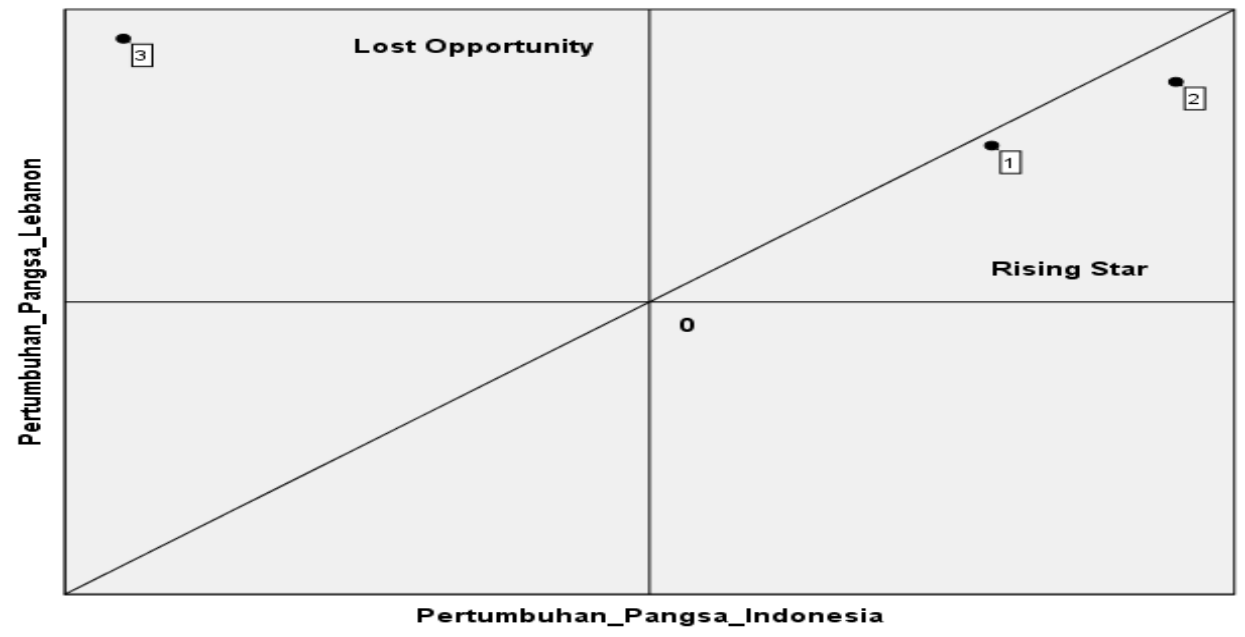

Gambar 8. Posisi Daya Saing Ekspor Produk Makanan Olahan Indonesia ke Lebanon, 2011-2015 and atalntic bonito...) 
Prepared or preserved tunas, skipjack and Atlantic bonito (HS 160414) dikategorikan sebagai LO. Hal ini menunjukkan Indonesia belum secara maksimal memanfaatkan peningkatan permintaan Lebanon untuk produk ini walaupun dari sisi nilai ekspor mengalami peningkatan namun lebih kecil dibandingkan peningkatan total ekspor Indonesia sehingga mengakibatkan penurunan daya saing produk ini.

\section{Posisi Daya Saing Produk Makanan Olahan Indonesia di Kuwait}

Pada tahun 2016 PDB Kuwait mencapai USD 114,04 miliar, dan tumbuh $1,8 \%$ dari PDB tahun sebelumnya. Struktur PDB Kuwait didominasi oleh sektor industri sebesar $51 \%$, sektor jasa sebesar $48 \%$ dan sektor pertanian sebesar $1 \%$. Adapun permintaan impor produk makanan olahan Kuwait dari dunia tumbuh ratarata 5,5\% per tahun (2012-2016).

Selama periode 2011 - 2015, terdapat 10 produk makanan olahan yang menjadi perhatian dalam perdagangan Indonesia dan Kuwait. Produk-produk ini memiliki potensi untuk dikembangkan, baik karena daya saing yang bagus dan didukung permintaan pasar yang tinggi. Namun, perlu menjadi perhatian Indonesia dalam mengelola pasar dan ekspornya ke Kuwait adalah produk-produk yang masuk dalam kategori LO. Produkproduk tersebut adalah; (1) Pineapple juice (HS200949); (2) Cocoa Powder, sweetened (HS 180610); (3) Chocolate and other food preparation containing cocoa (HS 180620); (4) Chocolate and other preparation containing cocoa (HS 180690); (5) Prepared or preserved tunas, skipjack and Atlantic bonito (HS160414); dan (6) Food Preparations consisting of finely (HS 210420).

Keenam produk makanan olahan ini tidak mampu mengambil kesempatan dari meningkatnya permintaan atas produk tersebut di pasar Kuwait. Analisis RCA dinamis menunjukkan bahwa penurunan pangsa pasar Indonesia terhadap produk tersebut sebesar $9 \%-90 \%$, sedangkan pertumbuhan pangsa pasar impor terhadap total impor makanan di Kuwait sekitar 7,5\% - 1.004,5\%. Produk makanan olahan Indonesia yang paling tinggi penurunannya adalah Prepared or preserved tunas, skipjack and Atlantic bonito (HS160414) sebesar 90\%, sedangkan produk yang paling tinggi pertumbuhan pangsa pasarnya di Kuwait Chocolate and other preparation containing cocoa (HS 180690) sebesar 1.004,5\%. 


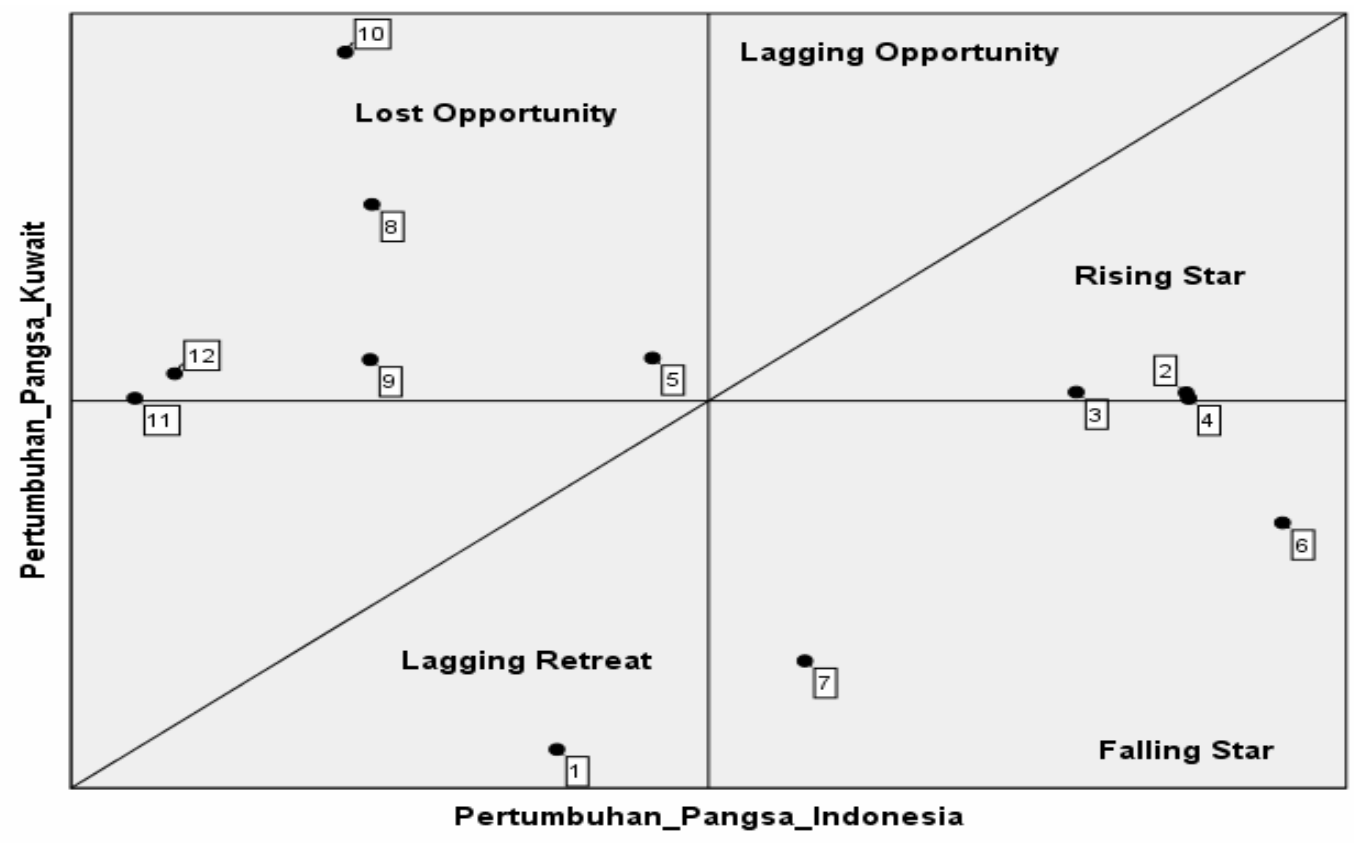

\section{Gambar 9. Posisi Daya Saing Ekspor Produk Makanan Olahan Indonesia ke Kuwait, 2011-2015}

Keterangan:

1. HS 200820 (pienapples, prepared or preserved wether or not containing added sugar...)

2. HS 190590 (bread, pastry, biscuits and other baker's...)

3. HS 210310 (soya sauce)

4. HS 210390 (preparations for sauces and prepared sauces..)

5. HS 200949 (Pineaplle juice, unfermented...)

6. HS 210690 (food preparations)

7. HS 200799 (jams, jellies, marmalades...)

Food Preparations (HS 210690) dan Jams (HS 200799) adalah produk yang menurun permintaan di pasar Kuwait. Keduanya masuk kategori falling star, yakni pangsa pasar produk tersebut di Indonesia mengalami kenaikan, disisi lain pangsa pasar Kuwait mengalami penurunan. Diduga penurunan pangsa pasar Kuwait kedua produk ini disebabkan adanya peningkatan impor produk tersebut, tapi tidak sebesar peningkatan total impor produk makanan olahan di Kuwait sendiri (2011 - 2015). Peningkatan pangsa
8. HS 180610 (cocoa poedwer, sweetened)

9. HS 180620 (Chocolate and other food preparations containg cocoa...)

10. HS 180690 (chocolate an other preparations containing cocoa...)

11. HS 160414 (prepared or preserved tunas, skipjack and atalntic bonito...)

12. HS 210420 (food preparations consisting of finely...)

pasar kedua produk ini masing-masing $54,29 \%$ dan $9,10 \%$. Sedangkan pangsa pasar di Kuwait mengalami penurunan sebesar $7,76 \%$ dan $16,56 \%$ untuk masing-masing kedua produk tersebut.

Produk pineapples, prepared or preserved (HS 200820) masuk dalam kategori Leading Retreat (LR), dimana kedua pangsa pasar baik Indonesia dan Kuwait mengalami penurunan. Penurunan bukan disebabkan oleh penurunan impor, namun lebih disebabkan oleh peningkatan impor 
atau ekspor produk tersebut lebih kecil dibandingkan peningkatan impor atau ekspor produk total sehingga mengakibatkan daya saing produk Indonesia mengalami penurunan.

\section{Posisi Daya Saing Produk Makanan} Olahan Indonesia di Jordania

Pada tahun 2016 PDB Jordania mencapai USD 38,65 miliar dan tingkat inflasi terjaga baik di level $1 \%$, yang mengindikasikan harga-harga di pasar domestik Jordania tidak mengalami fluktuasi dan relatif stabil. Dari sisi perdagangan luar negeri, Jordania memiliki keterbukaan yang cukup tinggi sebesar 9,3 dari skala 10 berdasarkan korelasi antara PDB dan tingkat keterbukaan pada perdagangan. Rata- rata permintaan produk makanan olahan Jordania dari dunia naik 7,7\% per tahun selama 2012-2016.

Di pasar Jordania, terdapat enam produk yang potensial untuk dikembangkan dan dapat dikategorikan ke dalam dua kelompok. Kelompok pertama adalah produk pasta cooked (HS 190230), extracts of coffee (HS 210111), waffles and wafers (HS 190532) dan prepared or preserved sardines, sardinella and brisling or sprats (HS 160413) yang dikategorikan sebagai rising star. Produk-produk ini mengalami peningkatan pangsa Indonesia yang lebih besar dibandingkan dengan pangsa di Jordania.

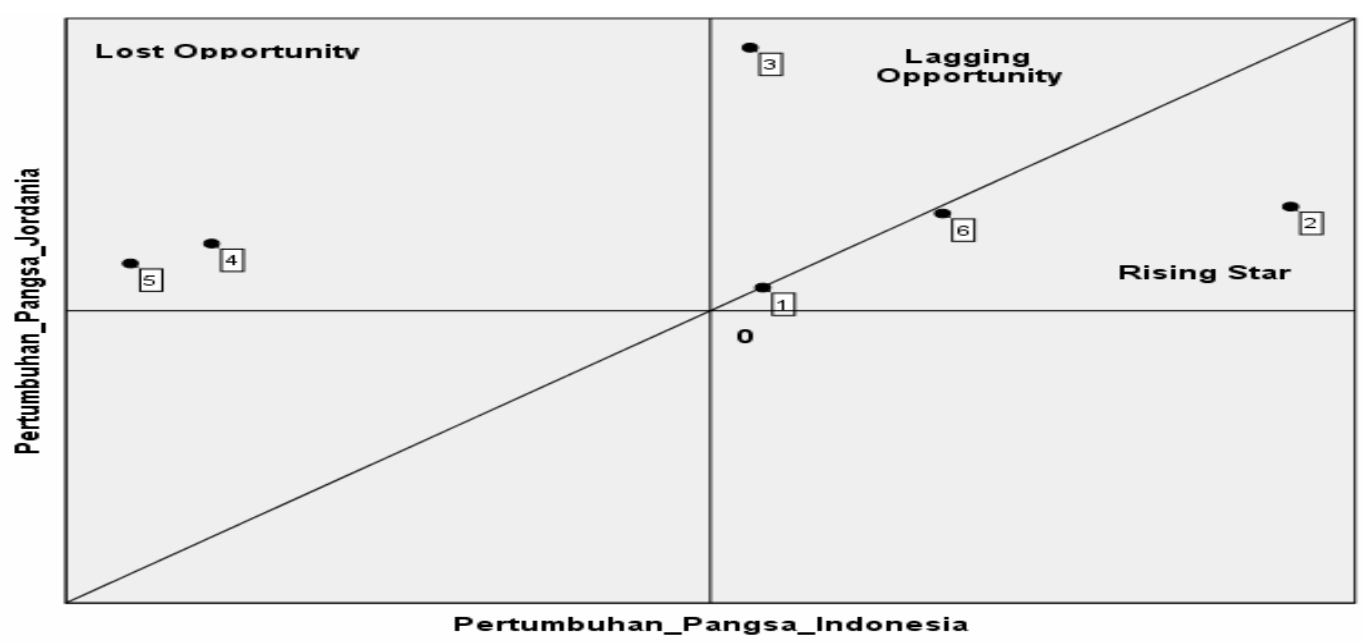

\section{Gambar 10. Posisi Daya Saing Ekspor Produk Makanan Olahan Indonesia ke Jordania, 2011-2015}

Keterangan:

1. HS 190230 (pasta, cooked or otherwise prepared)

2. HS 210111 (extracts, essence and concentrates...)

3. HS 190532 (waffles and wafers)

4. HS 190531 (sweet biscuits)
5. HS 160414 (prepared or preserved tunas, skipjack and atalntic bonito...)

6. HS 160413 (prepared or preserved sardines...) 
Kelompok kedua adalah LO, produk yang masuk dalam kategori ini adalah Sweet biscuits (HS 190531) dan Prepared or preserved tunas, skipjack and Atlantic bonito (HS 160414). Pada kedua kelompok ini, produk Indonesia tidak dapat mengambil kesempatan dari peningkatan pangsa Jordania bahkan pangsa Indonesia mengalami penurunan. Penurunan ini bukan diakibatkan oleh penurunan ekspor tapi lebih disebabkan peningkatan ekspor untuk kedua produk ini lebih kecil dibandingkan peningkatan total ekspor Indonesia.

\section{Posisi Daya Saing Produk Makanan Olahan Indonesia di Iran}

Tahun 2015, PDB Iran mencapai USD 412,2 miliar, menempatkan Iran sebagai negara dengan skala ekonomi terbesar ke-2 di kawasan Timur Tengah setelah Arab Saudi. Setelah sangsi embargo dicabut, Iran secara perlahan mulai memperbaiki ekonominya dengan meningkatkan produksi minyak bumi untuk mendapatkan kembali pangsa pasar yang telah diambil oleh negara pesaing selama embargo dikenakan. Ekspor minyak bumi meningkat sebesar $15 \%$ sejak Juli 2016 seiring peningkatan produksi yang mencapai 2 juta barel per hari. Sementara itu, tren permintaan produk makanan olahan Iran dari dunia naik 4,8\% per tahun selama 2012-2016.

Di pasar Iran, terdapat dua produk yang potensial untuk dikembangkan yaitu Sweet biscuits (HS 190531) dan Waffles and wafers (HS 190532). Kedua produk ini dapat dikategorikan dalam kelompok rising star. Hal ini menunjukkan bahwa produk Indonesia dapat mengambil kesempatan dari peningkatan permintaan untuk kedua produk tersebut di pasar Iran. Potensi pasar yang sangat baik di Iran, perlu dimanfaatkan dengan baik, hal ini dapat dilihat pangsa pasar Indonesia untuk kedua produk tersebut memiliki pertumbuhan yang sangat besar. Produk makanan waffles and wafers memiliki pertumbuhan pangsa pasar sebesar $9.965 \%$ dan pertumbuhan pangsa impor produk tersebut terhadap total impor makanan Iran sebesar $142,12 \%$ artinya Indonesia bisa meningkatkan dan mengambil keuntungan dengan menambah pasar hampir sampai puluhan kali. Begitu juga untuk produk Sweet biscuits yang memiliki pertumbuhan pangsa pasar di Indonesia sebesar $2.811 \%$, dan pertumbuhan pangsa impor produk tersebut terhadap total impor makanan Iran sebesar $739,12 \%$. 


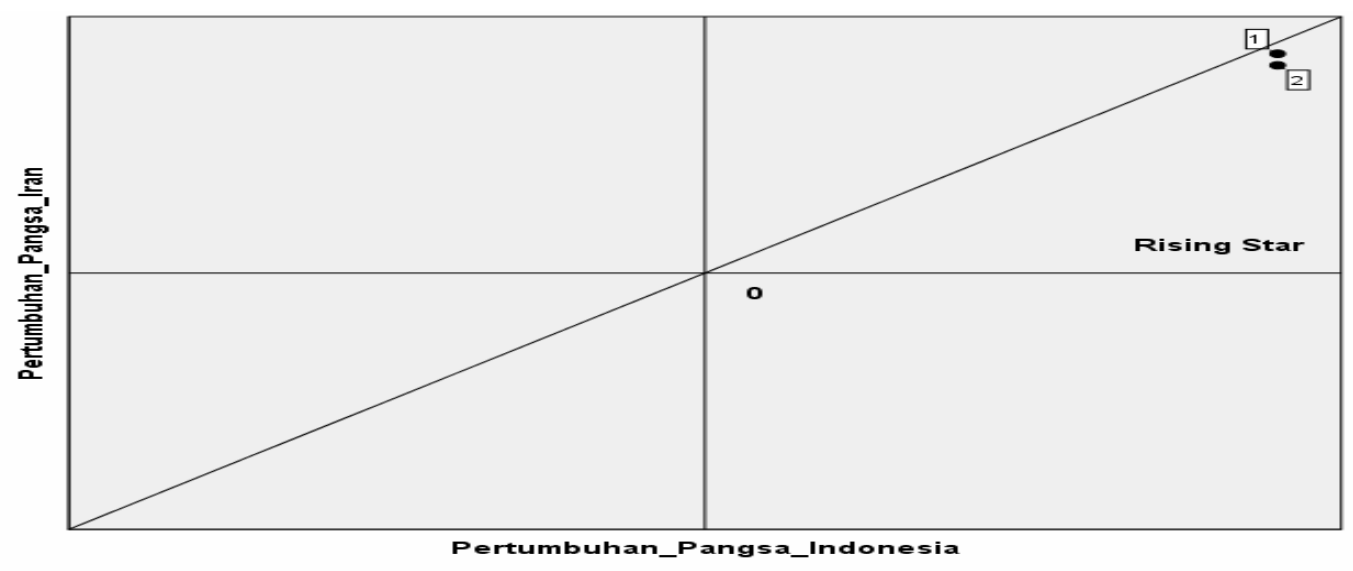

Gambar 11. Posisi Daya Saing Ekspor Produk Makanan Olahan Indonesia ke Iran, 2011-2015

Keterangan:

1. HS 190531 (sweet biscuits)

2. HS 190532 (waffles and wafer)

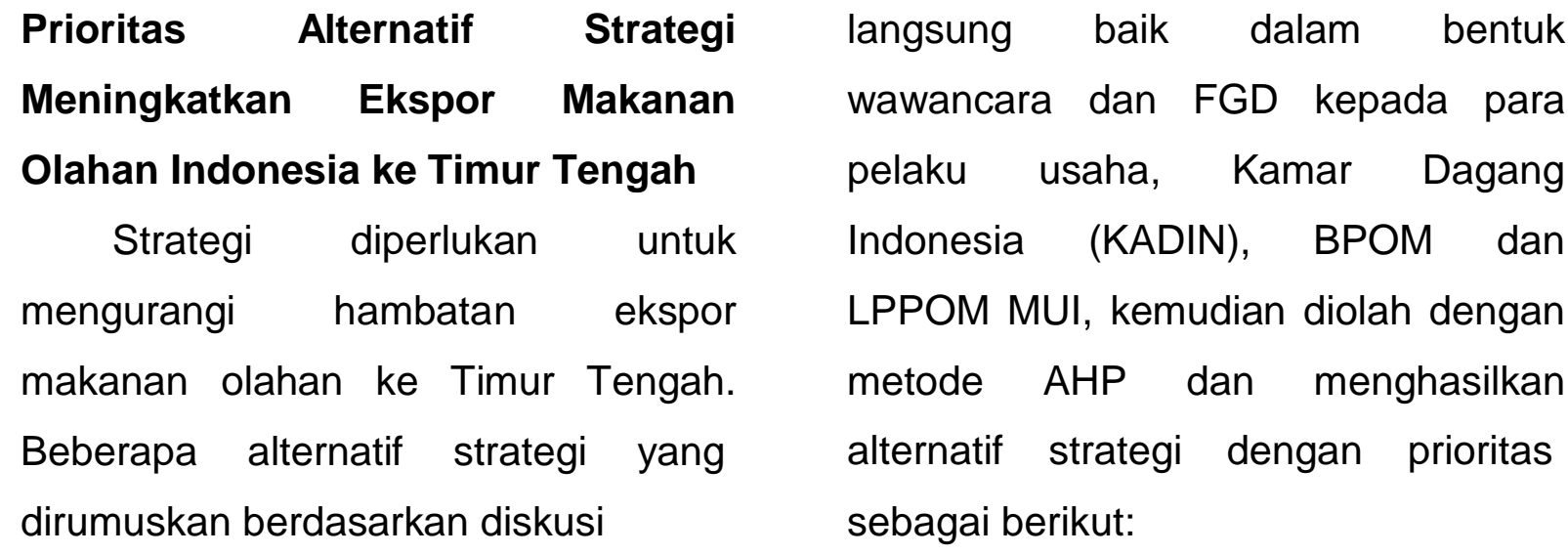

Tabel 2. Urutan Prioritas Alternatif Strategi Meningkatkan Ekspor Makanan Olahan Indonesia ke Timur Tengah

\begin{tabular}{lcc}
\hline \multicolumn{1}{c}{ Elemen Alternatif Strategi } & Bobot & Prioritas \\
\hline Ketersediaan Informasi Pasar Produk Makol, termasuk Budaya dan & 0,275 & 1 \\
Konsumen Negara Tujuan & 0,249 & 2 \\
Memenuhi Prosedur Kesehatan Pangan & 0,196 & 3 \\
Penurunan Tarif Impor di Negara Tujuan & 0,142 & 4 \\
Melakukan Promosi Dagang & 0,137 & 5 \\
\hline
\end{tabular}

Sumber: Hasil Analisis

KESIMPULAN DAN REKOMENDASI masing-masing makanan olahan KEBIJAKAN

Berdasarkan analisis RCA termasuk dalam Kategori Rising Star di Dinamis di 10 negara Timur Tengah, setiap negara yang dianalisis. 
Sedangkan produk yang perlu menjadi perhatian utama untuk ditingkatkan daya saingnya adalah produk yang masuk dalam kategori Lagging Opportunity (LagO) dan Lost Opportunity (LO) berdasarkan pemetaan produk makanan olahan Indonesia yang diekspor ke Timur Tengah. Pemilihan dua kategori ini dengan dasar pertimbangan, bahwa produk yang masuk pada kategori LagO mengindikasikan bahwa makanan olahan yang masuk ke negara Timur Tengah belum mampu memenuhi pertumbuhan pangsa pasar di negara tujuan, walaupun pertumbuhan pangsa pasar produk Indonesia tersebut juga memiliki pertumbuhan positif. Sedangkan, kategori LO mengindikasikan bahwa pangsa pasar produk Indonesia mengalami penurunan, namun disisi lain adanya peningkatan pertumbuhan pangsa pasar di Timur Tengah.

Berikut adalah produk yang termasuk dalam kategori LagO adalah produk Bread, pastry, cakes (HS 190590), Preparations for sauces (HS 210390), Waffles and wafers (HS 190532), Pineapple juice (HS 200949), Pasta (HS 190230) dan Soya sauce (HS 210310), Sedangkan produk yang masuk dalam kategori LO adalah
Bread, pastry, cakes (HS 190590), Sweet biscuits (HS 190531), Chocolate and other food preparations (HS 180620), Preparations for sauces (HS 210390), Mixtures of fruit juices (HS 200990), Waters, incl. mineral (HS 220210), Malt extract (HS 190190), Nuts and other seeds (HS 200819), Groundnuts (HS 200811), Pineapple juice (HS 200949), Cocoa powder, sweetened (HS 180610), Chewing gum (HS 170410), Chocolate and other preparations (HS 180690), Prepared or preserved tunas (HS 160414), Pineapples, prepared or preserved (HS 200820), Food preparations consisting of finely homogenised mixtures (HS 210420), dan Cereal products (HS 190410). Dari kedua kategori ini, terdapat beberapa produk yang beririsan, tergantung daya saing produk tersebut di masing-masing negara Timur Tengah.

Rekomendasi kebijakan yang diperlukan merupakan pelaksanaan dari alternatif strategi yang sudah disebutkan sebelumnya, sebagai upaya meningkatkan daya saing dan ekspor produk makanan olahan Indonesia ke Timur Tengah, antara lain:

Meningkatkan

peran Atase

Perdagangan dan Indonesian Trade Promotion Centre (ITPC) untuk 
memperoleh informasi pasar yang lebih mikro dan detail, sebagai upaya peningkatan upaya ekspor produk makanan olahan ke Timur Tengah; (2) Melakukan koordinasi dengan pihak terkait untuk memperoleh sertifikasi keamanan produk-produk makanan olahan yang berorientasi ekspor; (3) Mempercepat pembentukan perjanjian perdagangan dengan negara-negara Timur Tengah untuk memperluas akses pasar makanan olahan Indonesia; (4) Meningkatkan daya saing produk ekspor makanan olahan Indonesia dengan memberikan training dan pendampingan kepada eksportir UKM, termasuk dalam hal design dan packaging; (5) mengupayakan penyederhanaan dokumen ekspor di kedutaan negara Timur Tengah dengan biaya yang terjangkau.

\section{UCAPAN TERIMA KASIH}

Terima kasih kami sampaikan kepada Kepala Pusat Pengkajian Perdagangan Luar Negeri (Puska Daglu), Kementerian Perdagangan yang mengizinkan penulis untuk menggunakan hasil kajian ini untuk dipublikasikan. Ucapan terima kasih juga kami sampaikan kepada narasumber pendamping kajian dan rekan-rekan tim kajian yang memiliki andil besar dalam penyelesaian kajian dan tulisan ini.

\section{DAFTAR PUSTAKA}

Badan Pusat Statistik (BPS). (2017a). Statistik Ekspor Non Migas Indonesia. Jakarta.

Badan Pusat Statistik (BPS). (2017b). Produk Domestik Bruto per Triwulan Atas Dasar Harga Konstan 2000 Menurut Lapangan Usaha, 20002014 (Miliar Rupiah). Jakarta.

Edwards, L., Schoer, V. (2001). The Structure and Competitiveness of South African Trade. Trade and Industrial Policy Strategies (TIPS). 10-12 September 2001, pp. 1-37.

Fakhrudin, U., Hasni. (2009). Menentukan Produk Makanan Olahan Prioritas Ekspor Indonesia. Buletin IImiah Litbang Perdagangan Vol. 3 No. 1 Juli 2009, pp. 24-42.

Kathuria, L. M. (2013). Analyzing Competitiveness of Clothing Export Sector of India and Bangladesh: Dynamic Revealed Comparative Advantage Approach. Competitiveness Review: An International Business Journal. Vol. 23 No. 2, 2013, pp. 131-157.

Kementerian Perdagangan. (2015). Rencana Strategis Kementerian Perdagangan Tahun 2015-2019. Jakarta.

Lestari, W., Syarief, R., Sumantadunata, K. (2013). Strategi Peningkatan Daya Saing Tuna Olahan Indonesia di Pasar Internasional. Jurnal Manajemen IKM Vol. 8 No. 1. Februari 2013, pp. 36-44.

Marimin. (2004). Teknik dan Aplikasi Pengambilan Keputusan Kriteria Majemuk. Grasindo, Jakarta.

Miečinskienè, A., Stasytytè, V. Kazlauskaitè, J. (2014). Reasoning of export market selection. Procedia Social and Behavioral Sciences Vol. 110. pp. $1166-1175$. 
Nugroho, Agus. (2014). The Impact of Food Safety Standard on Indonesia's Coffee Exports. Procedia Environmental Sciences Vol. 20, pp. $425-433$.

Ozcelik, S.E., Erlat, G. (2013). Turkey's Comparative Advantages and Dynamic Market Positioning in the EU Market. Topics in Middle Eastern and African Economies. Vol. 15, No.2, September 2013, pp. 42-70.

Pusat Kebijakan Perdagangan Luar Negeri (Puskadaglu). Kemendag. (2013). Laporan Akhir Kajian Potensi Pengembangan Ekspor Ke Pasar Non Tradisional. Jakarta.

Ratanamaneichat, C., Rakkarn, S. (2013). Quality Assurance Development of Halal Food Products for Export to Indonesia. Procedia - Social and Behavioral Sciences Vol. 88, pp. 134 $-141$.

Rifin, A. (2013). Competitiveness of Indonesia's Cocoa Beans Export in the World Market. International Journal of Trade, Economics and Finance, 4(5), pp. 279-281.
Saaty, R. W. (1987). The Analytic Hierarchy Process-What It is and How It is Used. Mathematical Modelling, 9(3), 161-176.

Trademap. (2017). List of supplying markets from World Trade Organization (WTO) for a product group imported by Middle East.

Thuong, N.T.T. (2017). The effect of Sanitary and Phytosanitary measures on Vietnam's rice exports. EconomiA, pp. https://doi.org/10.1016/j.econ.2017.12 .001 .

Widyasanti, A. A. (2010). Perdagangan Bebas Regional dan Daya Saing Ekspor: Kasus Indonesia. Buletin Ekonomi Moneter dan Perbankan, Juli 2010, pp. 5-22.

World Bank. (2017). World Bank Country and Lending Groups. Diunduh tanggal 16 Januari 2017 dari https://datahelpdesk.worldbank.org/kn owledgebase/articles/906519-worldbank-country-and-lending-groups. 
